\title{
Synchrony between the Central Atlantic magmatic province and the Triassic-Jurassic mass-extinction event?
}

\author{
Jessica H. Whiteside ${ }^{\mathrm{a}, *}$, Paul E. Olsen ${ }^{\mathrm{b}}$, Dennis V. Kent ${ }^{\mathrm{b}, \mathrm{c}}$, \\ Sarah J. Fowell ${ }^{\mathrm{d}}$, Mohammed Et-Touhami ${ }^{\text {e }}$ \\ a Department of Geological Sciences, Brown University, 324 Brook Street, Box 1846, Providence RI 02912 \\ ${ }^{b}$ Department of Earth and Environmental Sciences, Lamont-Doherty Earth Observatory of Columbia University, 61 Route $9 \mathrm{~W}$, \\ Palisades, NY 10964, USA \\ ${ }^{\mathrm{c}}$ Department of Geological Sciences, Rutgers University, Piscataway, NJ 08554, USA \\ d Department of Geology and Geophysics, University of Alaska Fairbanks, Fairbanks, AK 99775, USA \\ e LGVBS, Département des Sciences de la Terre, Université Mohamed Premier, 60, 000 Oujda, Morocco
}

Received 15 March 2005; accepted 20 June 2006

\begin{abstract}
We present new data and a synthesis of cyclostratigraphic, lithostratigraphic, biostratigraphic, and published magnetostratigraphic and basalt geochemical data from eastern North America and Morocco in an attempt to clarify the temporal relationship between the Triassic-Jurassic mass extinction ( $202 \mathrm{Ma})$ and Earth's largest sequence of continental flood basalts, the Central Atlantic magmatic province (CAMP). Newly discovered zones of reverse polarity within CAMP flow sequences of Morocco have been hypothesized by Marzoli et al. [Marzoli, A., Bertrand, H., Knight, K.B., Cirilli, S., Buratti, N., Vérati, C., Nomade, S., Renne, P.R., Youbi, N., Martini, R., Allenbach, K., Neuwerth, R., Rapaille, C., Zaninetti, L., Bellieni, G., 2004. Synchrony of the Central Atlantic magmatic province and the Triassic-Jurassic boundary climatic and biotic crisis. Geology 32, 973-976.] and Knight et al. [Knight, K.B., Nomade, S., Renne, P.R., Marzoli, A., Betrand, H., Youbi, N., 2004. The Central Atlantic Magmatic Province at the Triassic-Jurassic boundary: paleomagnetic and ${ }^{40} \mathrm{Ar}{ }^{30} \mathrm{Ar}$ evidence from Morocco for brief, episodic volcanism. Earth and Planetary Science Letters 228, 143-160.] as correlates of a very short, uppermost Triassic age reverse chron in the Newark basin, thus suggesting that much of the Moroccan CAMP was synchronous with or predates the Triassic-Jurassic boundary. Here, however, we explain these apparent reverse polarity zones as possible correlatives of poorly sampled lower Jurassic basalt flow sequences and overlying strata in eastern North America and lower Jurassic reverse polarity sequences recognized by others in the Paris basin. A revised Milankovitch cyclostratigraphy based on new core and field data constrains the duration of eastern North America basaltic flows to $\sim 610 \mathrm{ky}$ after the Triassic-Jurassic palynological turnover event. Palynological data indicates correlation of the initial carbon isotopic excursion of Hesselbo et al. [Hesselbo, S.P., Robinson, S.A., Surlyk, F., Piasecki, S., 2002. Terrestrial and marine extinction at the Triassic-Jurassic boundary synchronized with major carbon-cycle perturbation: a link to initiation of massive volcanism. Geology 30, 251-254.] at St. Audrie's Bay to the palynological turnover event and vertebrate extinction level in eastern North America, suggesting a revised magnetostratigraphic correlation and robust carbon isotopic tests of the Marzoli-Knight hypothesis. We conclude that as yet there are no compelling data showing that any of the CAMP predated or was synchronous with the Triassic-Jurassic extinction event.
\end{abstract}

(C) 2006 Elsevier B.V. All rights reserved.

Keywords: Triassic; Jurassic; Mass extinction; Central Atlantic magmatic province; Magnetostratigraphy; Volcanism

\footnotetext{
* Corresponding author. Tel.: +1 401863 3339; fax: +1 4018632058.

E-mail address: Jessica_Whiteside@Brown.edu (J.H. Whiteside).
} 


\section{Introduction}

The $\sim 202$ Ma Triassic-Jurassic (T-J) event, one of the most severe mass extinctions of the Phanerozoic, was at least equal in intensity to the more famous CretaceousPaleogene boundary (depending on the metric; Benton, 1995; Foote, 2003; contra Tanner et al., 2003). Suggested causes for the T-J mass extinction include sea-level change and anoxia (Hallam, 1990), a methane- and $\mathrm{CO}_{2}$-generated super-greenhouse triggered by flood basalt eruptions (McElwain et al., 1999; Hesselbo et al., 2002; Beerling and Berner, 2002), and extraterrestrial impact(s) (Olsen et al., 1987; Bice et al., 1992; Olsen et al., 1992; Spray et al., 1998; Ward et al., 2001; Olsen et al., 2002a,b). The T-J mass extinction may have fortuitously enabled ecological ascent of dinosaurs much as the Cretaceous-Paleogene mass extinction cleared the way for mammalian and avian dominance (Olsen et al., 2002a).

The T-J extinction horizon, variously defined, is characterized by a modest Ir anomaly (Olsen et al., 2002a), a spike in fern spore abundance (Fowell and Olsen, 1993), a negative $\delta^{13} \mathrm{C}$ excursion (Pálfy et al., 2001; Ward et al., 2001; Hesselbo et al., 2002) and stomatal density changes that suggest an increase in atmospheric $\mathrm{CO}_{2}$ (McElwain et al., 1999), and the temporally proximate continental flood basalts of the Central Atlantic magmatic province (CAMP) (Rampino and Stothers, 1988; Marzoli et al., 1999). Definitive evidence for an asteroid impact is lacking, and the boundary data are potentially also consistent with consequences of the extensive flood basalts. Although the initiation of the CAMP was undoubtedly close to the T-J extinction event, superposition in sections in all major eastern North American basins with basalts provides strong evidence that all the flows post-date the local expression of what has been recognized as the extinction level (cf., Cornet, 1977; Cornet and Olsen, 1985; Fowell and Olsen, 1993; Fowell et al., 1994; Fowell and Traverse, 1995). These observations imply that the visible manifestations of the CAMP eruptive phases were not responsible for the extinctions.

Marzoli et al. (2004) and Knight et al. (2004), however, interpret stratigraphic palynologic, geochronologic, palaeomagnetic, and basalt geochemical data from Morocco to mean that the oldest (Moroccan) CAMP eruptions predated or were synchronous with the T-J boundary, suggesting a causal relationship between volcanism and the mass extinction (Fig. 2). The MarzoliKnight hypothesis generates an explicit, data-driven, testable hypothesis that correlates the CAMP to the palynological turnover event, and hence, the T-J mass extinction in general.
In this paper, we examine the evidence for the relative age of the CAMP and the T-J palynological turnover event in eastern North America and Morocco, present new litho-, cyclo-, and bio-stratigraphic data and conclude that there is still no compelling pre-Jurassic CAMP in Morocco or elsewhere, and propose tests of this interpretation.

\section{The Central Atlantic magmatic province}

The most aerially extensive continental flood basalt province on Earth, the Central Atlantic magmatic province, extends over $7 \times 10^{6} \mathrm{~km}^{2}$ and consists mostly of tholeiitic basalts and mafic intrusions preserved on four continents (Marzoli et al., 1999). Although deeply eroded, the CAMP is preserved in the southern half of the Early Mesozoic rift zone that stretched from Greenland and Europe through eastern and southeastern North America and northwest Africa, where it is represented by thick basalt flows and associated intrusions emplaced at least $32 \mathrm{Ma}$ after continental rifting began. Remnants are also spread over large areas of South America and central West Africa. In the best studied areas (eastern North America and Morocco), the flows and associated intrusions exhibit remarkable lateral geochemical consistency. The numerous dikes that evidently fed the CAMP form a crude radiating pattern, the center of which lies offshore the southeastern United States, perhaps marking a mantle plume source for the province (Fig. 1) (e.g., May, 1971; Oliveira et al., 1990; Hill, 1991; Ernst and Buchan, 1997).

\section{CAMP and the T-J palynological turnover event in eastern North America}

Dominantly tholeiitic flows of the CAMP crop out in all of the exposed eastern North American basins with Jurassic age strata. These petrologically rare olivineand common quartz-normative basaltic units are laterally extensive and reach a maximum thickness of $1 \mathrm{~km}$ exclusive of interbedded sediments. Flows are intercalated with cyclical lacustrine strata exhibiting Milankovitch frequencies (Olsen, 1984; Olsen and Kent, 1996; Olsen et al., 1996a, 2003a).

Four geochemically distinct, quartz normative groups are recognized (Puffer and Lechler, 1980; Puffer et al., 1981; Ragland and Whittington, 1983; Philpotts and Reichenbach, 1985; Puffer and Philpotts, 1988; Greenough et al., 1989; Tollo and Gottfried, 1992; Dostal and Greenough, 1992). In the classification of Weigand and Ragland (1970) and Ragland and Whittington (1983), the oldest flows of the CAMP in eastern North America are High Titanium Quartz Normative (HTQ) basalts. High Iron Quartz Normative (HFQ) basalts are stratigraphically 


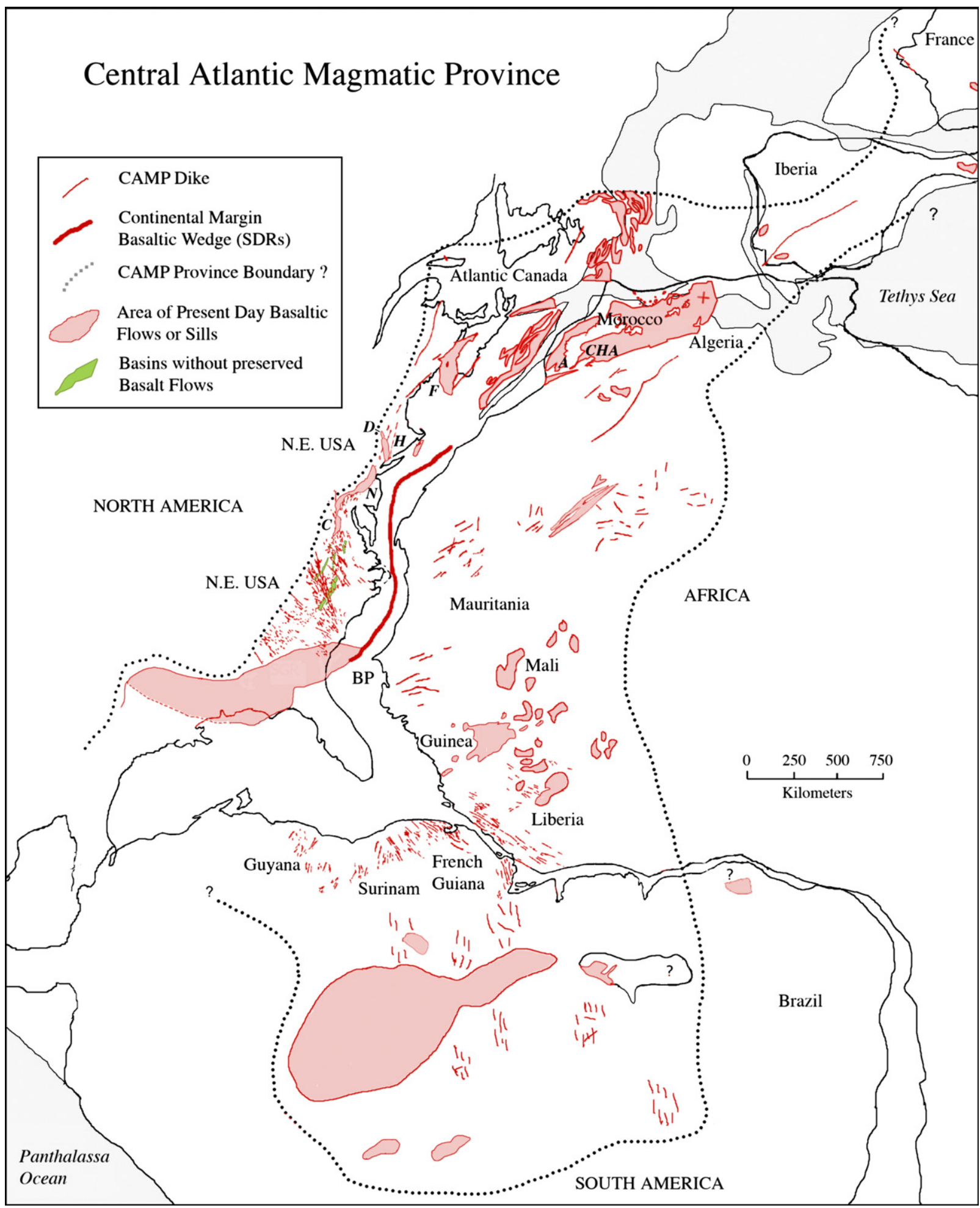

Fig. 1. Distribution of the CAMP in central Pangea showing basins described in text. Modified from McHone (2000). 


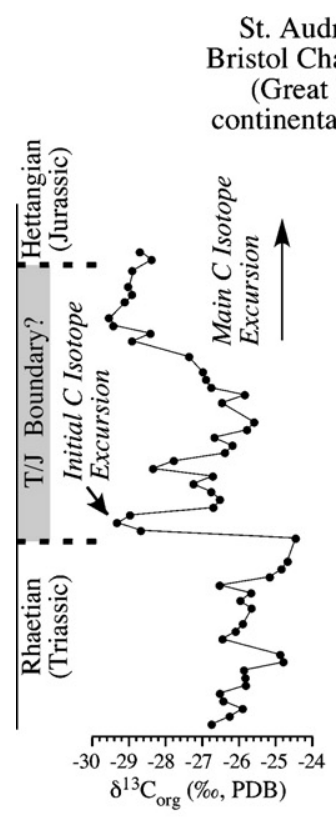

$$
\begin{array}{cc}
\text { Newark Basin } & \begin{array}{c}
\text { Central High Atlas } \\
\text { (New Jersey, USA) } \\
\text { continental }
\end{array} \\
\text { continental }
\end{array}
$$

arine

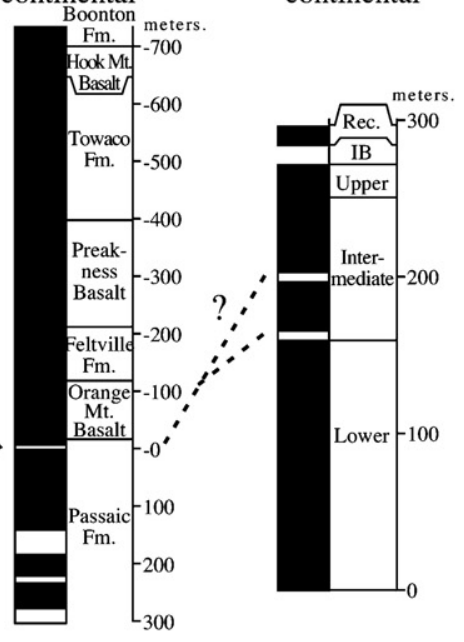

SA5n.2n
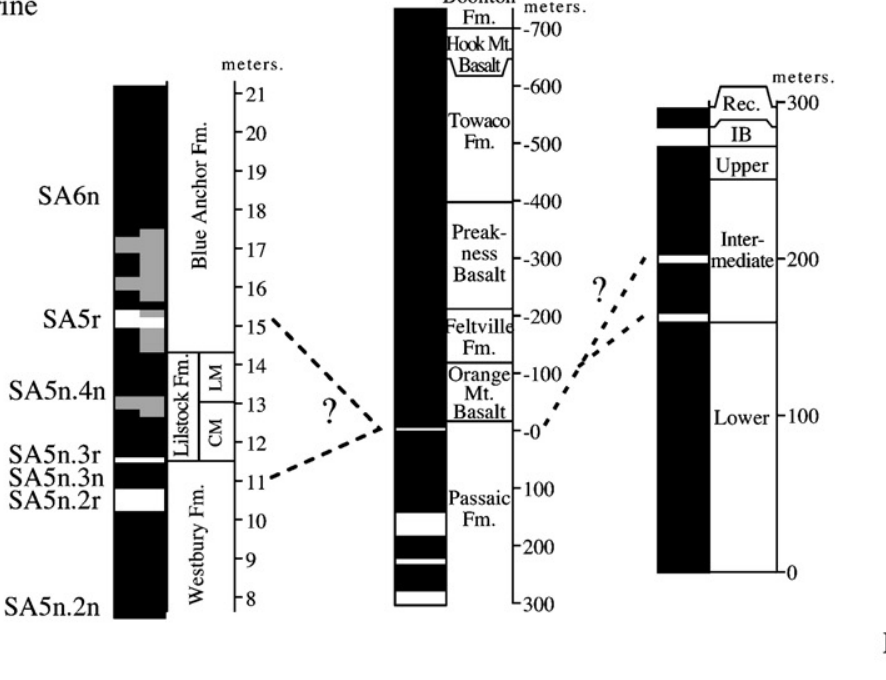

Moncornet Core

Paris Basin

(France, marine)
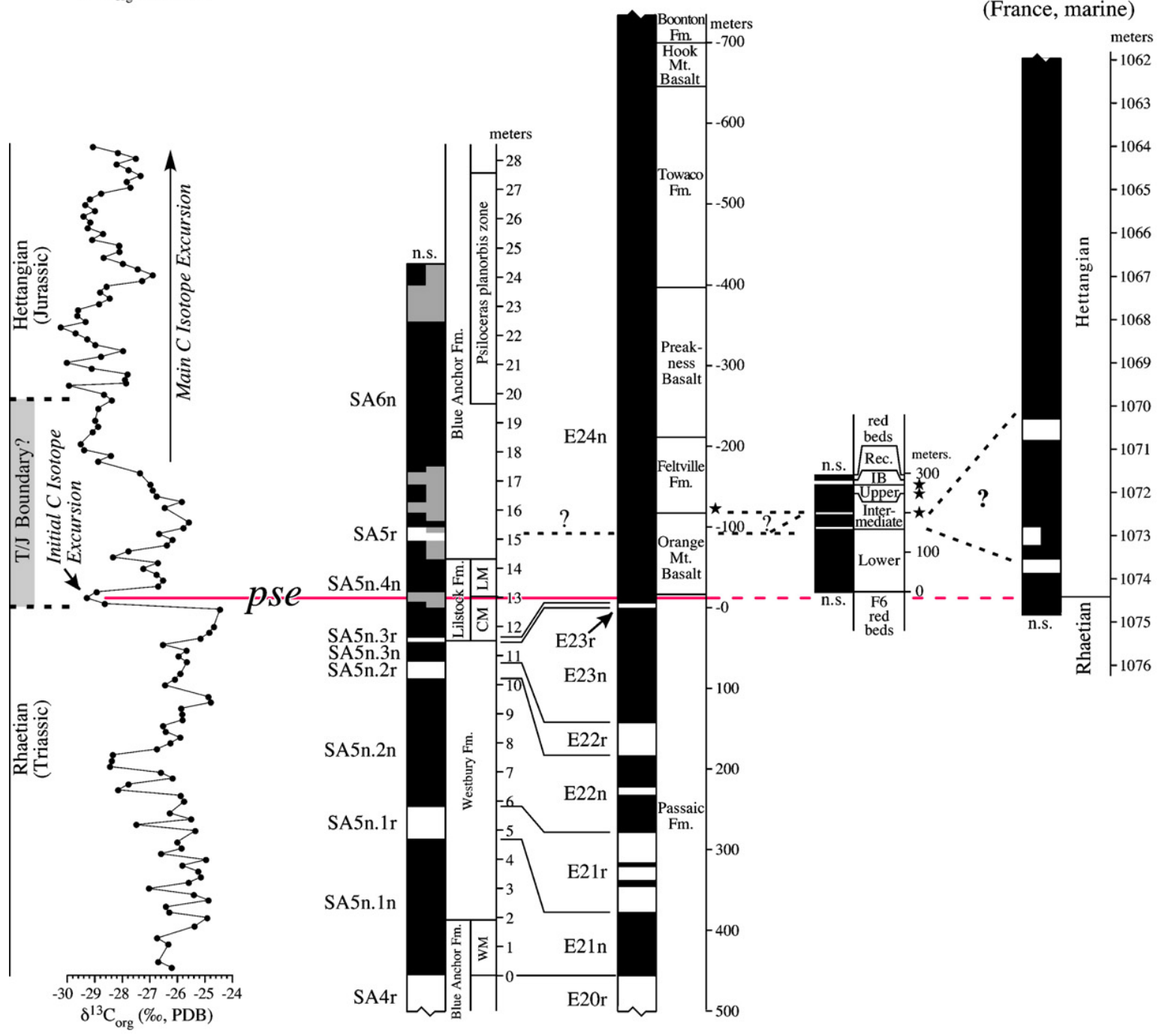
distinct from the HTQ basalts and closely associated with rare Low Titanium Quartz Normative (LTQ) basalts. Sedimentary rocks separate the youngest basalt flows of High Iron High Titanium Quartz Normative (HFTQ) composition from the older basalts (Fig. 3A).

The stratigraphic interval identified by most workers as the T-J boundary in the continental rift strata of eastern North America (Fig. 3A) is recognized by the last appearances of Ovalipollis ovalis, Vallasporites ignacii, and Patinasporites densus, among other sporomorphs (Cornet, 1977; Cornet and Olsen, 1985; Fowell et al., 1994). The cheirolepidiaceous pollen taxa Classopollis spp. increase to relatively high but erratic $(\sim 60 \%)$ percentages well below the extinction level while consistently high levels (+90\%), consisting most of Classopollis meyeriana (=Gliscopollis), are restricted to younger strata above the extinction horizon. For clarity, we will refer to this level as the T-J palynological turnover event. A very similar and plausibly correlative pattern is seen in palyniferous marine sections (Hounslow et al., 2004, references therein). The T$\mathrm{J}$ boundary is, however, often recognized in marine strata (including potential GSSPs) by the first appearance of an ammonite of Jurassic aspect (e.g., Psiloceras planorbis), rather than the underlying extinction event. In the latter scheme, the palynological (and invertebrate) extinctions would fall within the Triassic. We note that the position of the T-J boundary has not been formally defined, and we therefore refer explicitly to the events themselves rather than an as yet undetermined definition.

\subsection{Newark basin}

The Newark basin is the most well known of the Pangaean rift basins due to extensive study of outcrops and cores (e.g., Olsen et al., 1996a,b) (Fig. 3A and B). Milankovitch-modulated red, gray, and black lacustrine strata dominate these sections and serve as the basis for an astronomically calibrated palaeomagnetic reversal time scale for the Late Triassic and Early Jurassic (Kent et al., 1995; Kent and Olsen, 1999).

The T-J palynological turnover event and its relationship to the CAMP flows have been most extensively studied in the Jacksonwald syncline in the southeastern corner of the Newark basin (Exeter Township, PA) $\left(19^{\circ} \mathrm{N}\right.$ palaeolatitude; Kent and Tauxe, 2005). There, cyclos- tratigraphy constrains the palynological turnover event, associated Ir anomaly (maximum of $280 \mathrm{ppt}$ ), and spike in fern spore abundance to a brief $(<10 \mathrm{ky})$ interval, less than one precessional cycle $(\sim 20 \mathrm{ky})$ below the Orange Mountain Basalt of HTQ composition, the oldest flow sequence in the basin. Terrestrial vertebrate footprints also record a dramatic concentration of last occurrences, with the inferred extinction interval overlapping the palynological turnover event within the sampling resolution of $<30 \mathrm{ky}$ (Olsen et al., 2002a,b). The 1.3-km section of Jurassic (Hettangian Age) lacustrine strata that overlies the palynological turnover event intercalate with the basalts of HTQ (Orange Mountain), HFQ and LTQ (Preakness), and HFTQ (Hook Mountain) compositions. These strata have archetypal Jurassic terrestrial assemblages: low diversity, Classopollis-dominated palynofloras and low diversity, dinosaur- and crocodylomorphdominated tetrapod assemblages.

A thin zone of reverse magnetic polarity (E23r) exists a few metres below the palynological turnover event and its correlative level (Fig. 2) in three Newark basin sections separated by a total of $125 \mathrm{~km}$ (Kent et al., 1995; Olsen et al., 1996a; Kent and Olsen, 1999). Only normal magnetizations have been recovered thus far in the overlying sedimentary rocks and CAMP flows (McIntosh et al., 1985; Witte and Kent, 1990; Witte et al., 1991; Kent et al., 1995). Chron E23r, with an estimated duration of less than $30 \mathrm{ky}$ (Kent and Olsen, 1999), is thus crucial for correlation between eastern North America, Morocco, and Great Britain (Fig. 2).

\subsection{Culpeper Basin}

The southernmost exposed basin with basalt flows, the Culpeper basin $\left(17^{\circ} \mathrm{N}\right.$ palaeolatitude; Kent and Tauxe, 2005), has a thick sequence of flows (1.6 km inclusive of interbedded sediments) similar to that of the Newark basin. There is a lower HTQ basalt flow (Mt. Zion Church Basalt) succeeded by cyclical sedimentary strata of the Midland Formation followed by a thick $(\sim 1.1 \mathrm{~km})$ complex of HFQ and LTQ basalts with interbedded sedimentary strata. Cyclical lacustrine strata overlie the basalt flow sequence. HFTQ flows are absent.

The highest Triassic-aspect palynomorph assemblages occur within the Catharpin Creek Formation

Fig. 2. Above: the Marzoli-Knight hypothesis showing correlation of Moroccan CAMP magnetostratigraphy with that of the Martinsville no. 1 core of the Newark basin (Kent et al., 1995) and St. Audrie's Bay section (Hounslow et al., 2004) and $\delta^{13} \mathrm{C}$ data from St. Audrie's Bay (Hesselbo et al., 2002) (modified from Knight et al., 2004). Below: hypothesis of correlation favored here showing the same sections with the addition of the Moncornet core section form the Paris basin (Yang et al., 1996). In this hypothesis, sections are correlated on the basis of the pollen and spore extinction level ( $p s e$ ). Abbreviations are CM, Cotham Member; IB, sedimentary interbed between upper and recurrent basalt units; LM, Langport Member; n.s., not sampled; pse, pollen and spore extinction level; $\star$ (star), well-developed carbonate levels. 
(Fowell and Olsen, 1993), $10 \mathrm{~m}$ below the Mt. Zion Church Basalt. Strata directly overlying the basalt are of typical Jurassic character (as are all succeeding strata). Lack of long continuous sections precludes precise location of the palynological extinction event and a measured section is hence not shown in Fig. 3A. All of the sparsely sampled basalt flows are of normal polarity (Hozik, 1992).

\subsection{Hartford and Deerfield Basins}

The CAMP successions and sedimentary interbeds of the Hartford and Deerfield basins $\left(20^{\circ} \mathrm{N}\right.$ palaeolatitude; Kent and Tauxe, 2005) are generally similar to those of the homotaxial Newark basin, except that the basalts tend to be thinner and LTQ-type flows are absent. Nearly all of the pre-CAMP strata are fluvial (New Haven and Sugarloaf formations). The uppermost few metres of the New Haven Formation, however, yield a Classopollis-dominated palynomorph assemblage lacking Triassic age taxa (Heilman, 1987; Olsen et al., 2002b). The New Haven Formation is overlain by HTQ flows of the Talcott Formation and a succession of cyclical lacustrine strata interbedded with and overlying HFQ (Holyoke) and HFTQ (Hampden) basalts (Fig. 3A and B).

Physically connected to the Hartford basin, the Deerfield basin has one basalt flow formation, the Deerfield Basalt of HFQ composition. Underlying strata of the Fall River beds are assigned to the early Jurassic based on palynomorph assemblages (Cornet, 1977; Olsen et al., 1989). The exact relationship between the Jurassic Fall River beds, the underlying Sugarloaf Formation of presumed Triassic age, and the T-J palynological turnover event is unknown, although a minor unconformity has been postulated (Olsen, 1997; Hubert and Dutcher, 1999). Cyclostratigraphy of the strata overlying the Deerfield basalt is virtually identical to that of the Towaco and East Berlin formations (of the Newark and Hartford basins, respectively), both of which overlie HFQ flow sequences (Olsen et al., 1989).

\subsection{Fundy Basin}

The CAMP basalt flows of the Fundy basin $\left(24^{\circ} \mathrm{N}\right.$ palaeolatitude; Kent and Tauxe, 2005) are the most northern to crop out in eastern North America. They are interbedded with cyclical lacustrine facies of distinctly arid aspect relative to the strata that crop out in rift basins to the south. The single basalt formation, the North Mountain Basalt of HTQ composition lacks significant sedimentary interbeds. Beneath the North Mountain Basalt, the Blomidon Formation consists primarily of cyclical, eolian- and evaporite-bearing mudstones and sandstones. The upper few metres of the formation, where not contact metamorphosed, are consistently comprised of a variegated sequence of palyniferous red, gray, and black cyclical lacustrine strata that contain the T-J palynological turnover event (Fowell and Traverse, 1995). As in the Newark basin,

Fig. 3. (A) Measured Triassic-Jurassic sections from the Newark, Hartford, Deerfield, Argana, Central High Atlas, and Fundy basins showing the distribution of lacustrine strata of different colours. Darker colours generally conform to units exhibiting deeper water lacustrine facies, while more purple and red colours correspond to shallower and drier lacustrine facies, except in the cases of the New Haven (NH) and Sugarloaf (SA) formations, and Fall River (FB) beds, which are in part fluvial, and the white limestones that can also be partially fluvial. Abbreviations for lithological units are AB, Argana Basalt; BIG, Bigoudine Formation; BLOM, Blomidon Formation; BOON, Boonton Formation; DB, Deerfield Basalt; EBER, East Berlin Formation; F6, unit F6 (not formally named); FB, Fall River beds; FELT, Feltville Formation; HB, Hampden Basalt; HMB, Hook Mountain Basalt; HOLB, Holyoke Basalt; IU, intermediate basalt unit; LU, lower basalt unit; MCB, McCoy Brook Formation; NH, New Haven Formation; NMB, North Mountain Basalt; OMB, Orange Mountain Basalt; PASS, Passaic Formation; PB, Preakness Basalt; PORT, Portland Formation; RB, recurrent basalt unit; SA, Sugarloaf Arkose; SHUT, Shuttle Meadow Formation; T9, sedimentary unit T9 (not formally named); TB, Talcott Formation; TFF, Turners Falls Formation; TOW, Towaco Formation; UU, upper basalt unit. Abbreviations for measured sections are: A, Martinsville no. 1 core; B, ACE, Army Corps of Engineers cores (from Olsen et al., 1996b); C, Park River Cores, Hartford, CT; D, East Berlin road cut (from Olsen et al., 1989); E, Sugar Loaf tunnel (from Olsen et al., 1989); F, Roses Brook (from Olsen et al., 1989); G, Cooks Gap (from Gierlowski-Kordesch and Huber, 1995); H, Silver Ridge exposures (from Olsen et al., 2003b); Silver Ridge B-1 core; J, Silver Ridge B-2 core; K, Turners Falls section (from Olsen et al., 1989); L, Rt., 2 cut, Gill, MA (from Olsen et al., 1989); M, hill slope outcrop and Road cut, Alemzi north near Bigoudine, Morocco; N, Alemzi north (from Ait Chayeb et al., 1998); O, outcrops near Aoudjou, Morocco; P, outcrops near Ait Ourir, Morocco; Q, outcrops at Sidi Rahhal, Morocco; R, near Ait Ourir (from Bertrand, 1991); S, road cut and outcrops east of Sidi Rahhal; T, outcrops at Oued Lahr (from Knight et al., 2004 - background data); U, outcrops near Ross Creek, Nova Scotia (from Olsen et al., 1989); V, GAV-77-3 core (from Kent and Olsen, 2000). Palaeolatitudes from Kent and Tauxe, 2005). Arrows with bar at apex are significant carbonate-rich intervals. Culpeper section not shown because sufficient measured sections do not yet exist. (B) Cyclostratigraphic correlation of sections shown in (A); key for lithologies is the same as in (A). Precession curve is calculated for the Late Triassic and Early Jurassic using the fundamental frequencies g2 and g5 from Laskar et al. (2004), mean Triassic fundamental frequencies of g3 and g4 from Olsen and Kent (1999) based on geological data, a precessional constant for 202 Ma based on Berger et al. (1992), and amplitudes based on Laskar et al. (2004). Abbreviations are: $c l$, Significant macrofloral remains of Clathropteris; $j f$, footprint assemblage of Jurassic (Connecticut Valley) aspect; $j i$, dwarf mollusk assemblage; jp, Palynological assemblage of Jurassic aspect; 1s, significant limestone intervals; trf, footprint assemblage of Triassic aspect; trp, palynological assemblage of Triassic character. 


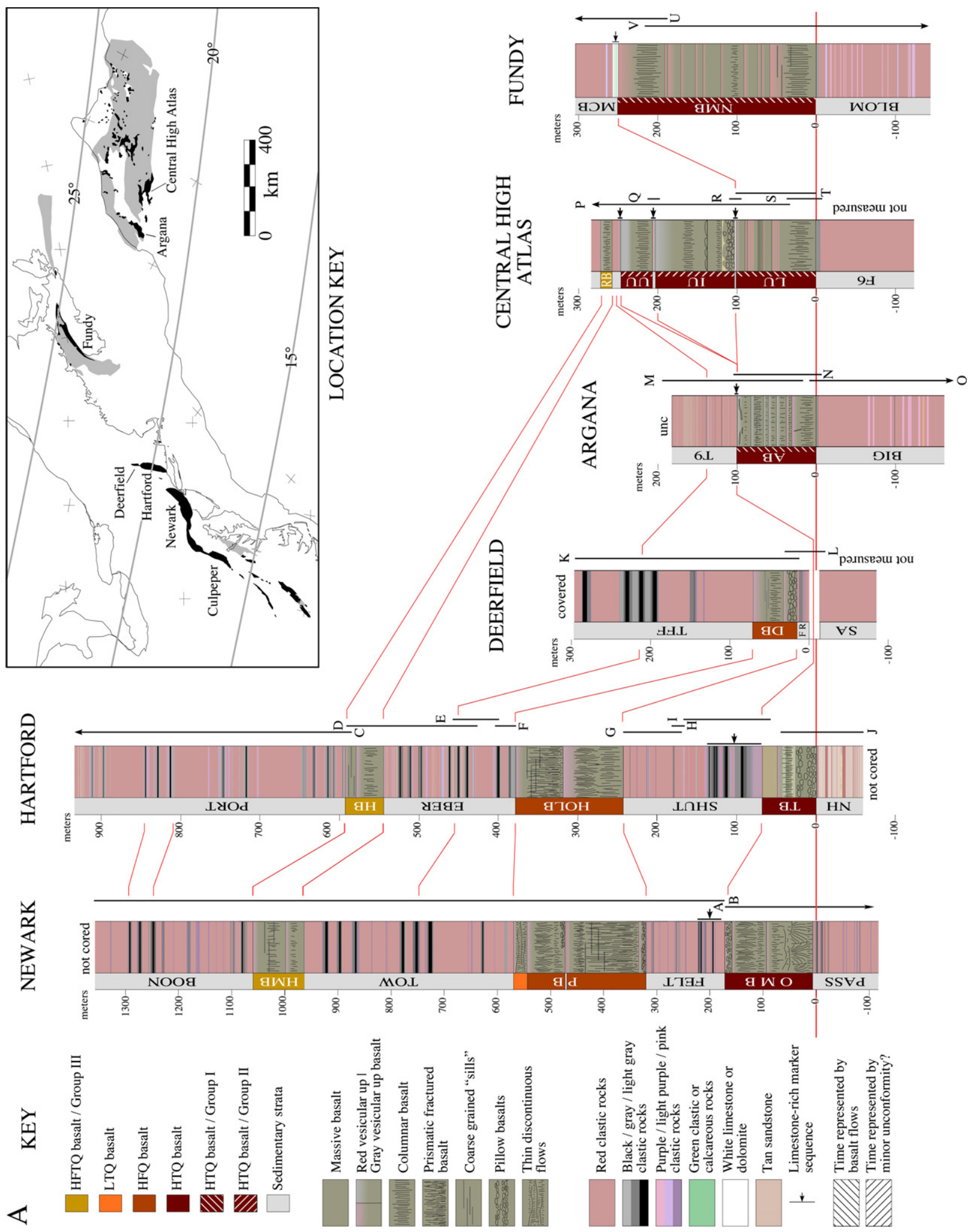




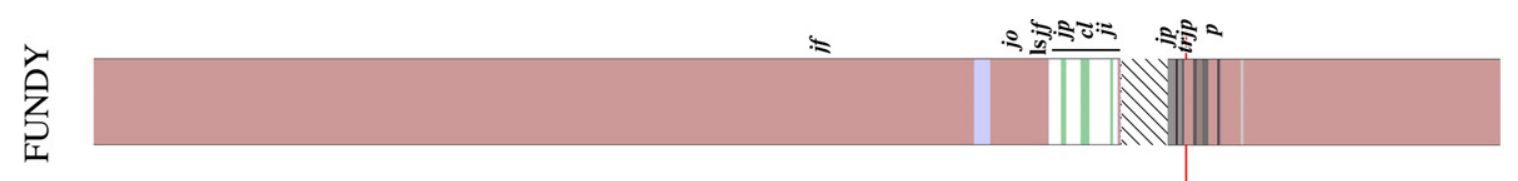

苞

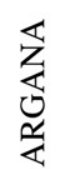
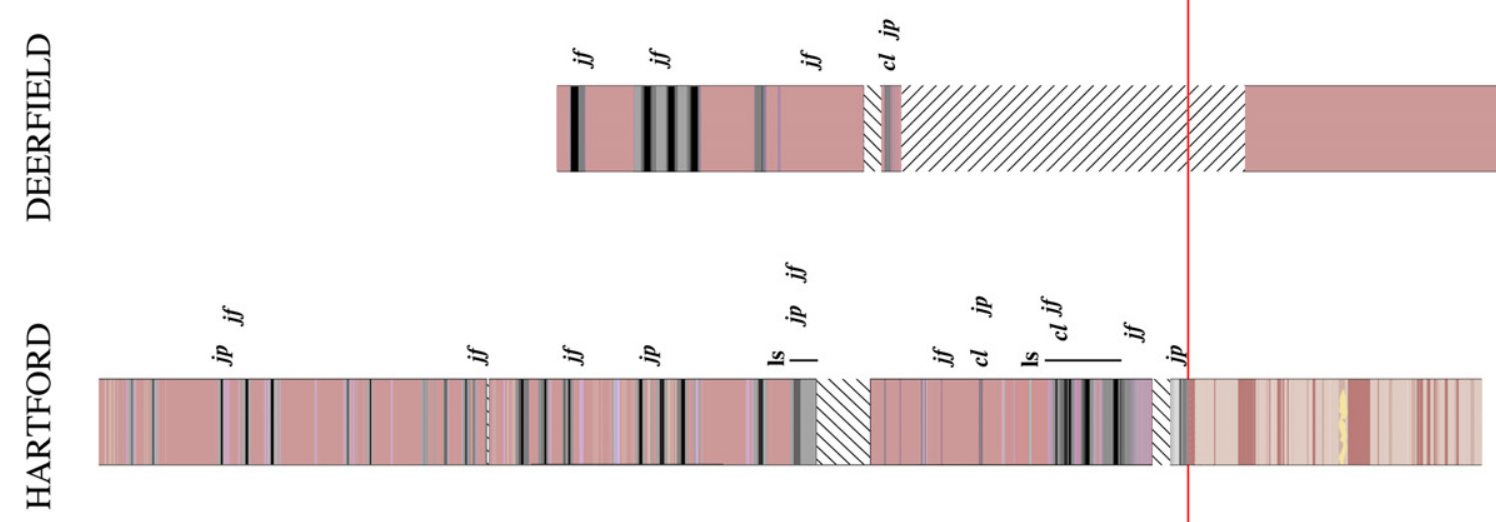

FE

氙
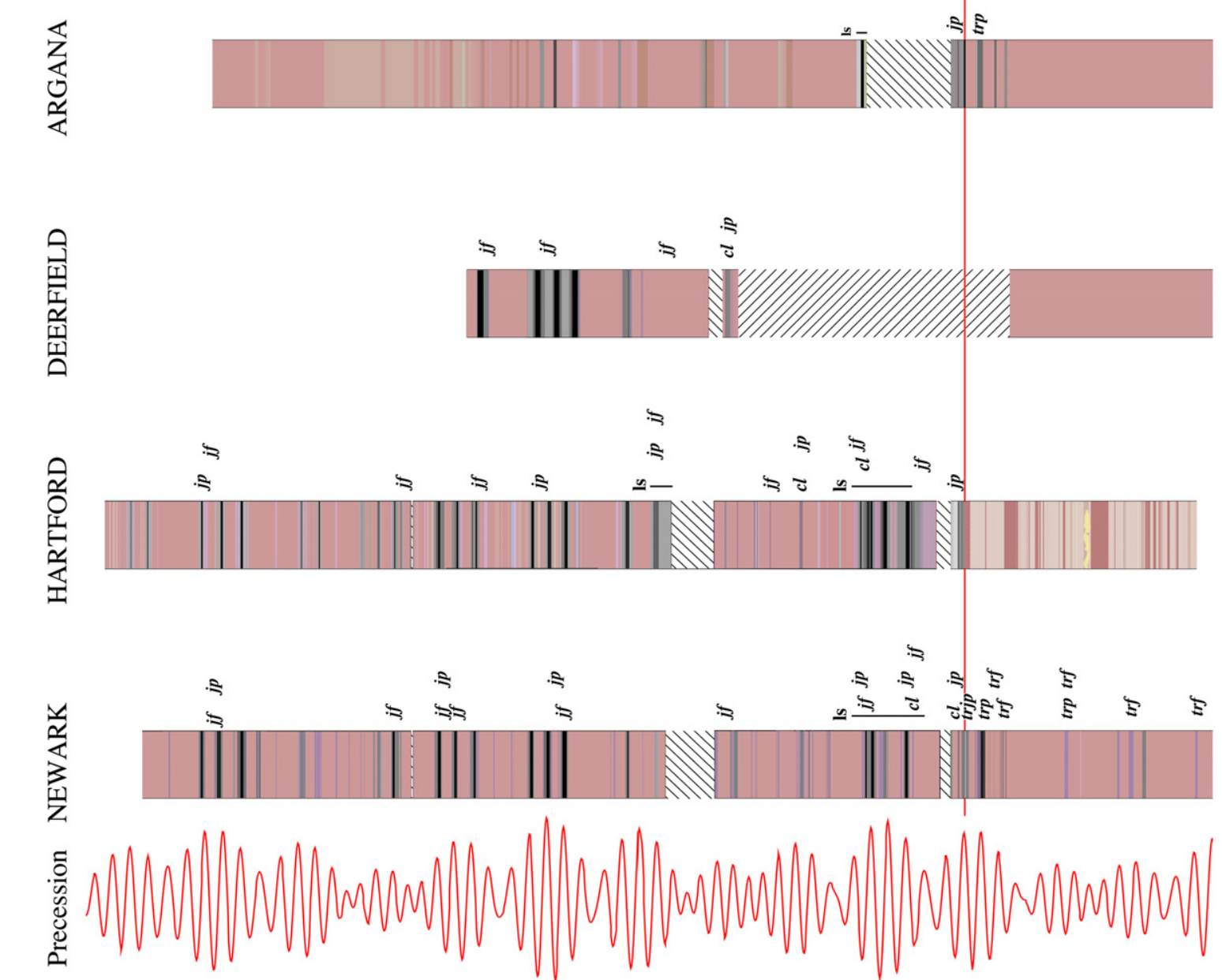

\begin{tabular}{|c|c|c|c|c|c|c|c|c|c|c|c|c|c|c|}
\hline \multirow{2}{*}{$\begin{array}{l}\bar{\Xi} \\
\text { ज्ञ }\end{array}$} & $\varepsilon^{001} \mathrm{G}$ & $z^{001}$ 马 & $\mathrm{I}^{001 \mathrm{I}}$ & $t^{001} \mathrm{~B}$ & $\varepsilon^{001} \mathrm{~B}$ & $\tau^{001} \mathrm{~B}$ & $\mathrm{I}^{001} \mathrm{G}$ & $t^{001} \mathrm{~g}$ & $\varepsilon^{001} \mathrm{~g}$ & $\mathrm{Z}^{001} \mathrm{~g}$ & $\mathrm{I}^{00 \mathrm{I}} \mathrm{B}$ & ${ }^{001} I_{B}$ & $\varepsilon^{001} \mathrm{~g}$ & $z^{001} \mathrm{~B}$ \\
\hline & \multicolumn{3}{|c|}{$\mathrm{EH}^{000} \mathrm{~g}$} & \multicolumn{4}{|c|}{$\mathrm{ZH}^{000 t} \mathrm{~B}$} & \multicolumn{4}{|c|}{$\mathrm{IHH}^{00 \mathrm{t}} \mathrm{B}$} & \multicolumn{3}{|c|}{$00 d^{+} I^{00 t} \mathrm{~g}$} \\
\hline & 8 & $\infty$ & 8 & \& & 8 & 1 & & & & & & $\frac{8}{6}$ & & \\
\hline
\end{tabular}


the palynological turnover event is coincident with a modest Ir anomaly ( 300 ppt, Tanner and Kyte, 2005). Fundy basin sections that contain the extinction level differ from those in the Newark basin by having much lower accumulation rates (Olsen et al., 2002b, 2005).

Partridge Island in Nova Scotia provides the most intensively studied boundary section (Fowell and Traverse, 1995). This section is often obscured by talus and was manually excavated for over $10 \mathrm{~m}$ to determine the lateral persistence of units at the outcrop scale. We resampled this section at higher resolution and provide a new set of palynological analyses. Samples (Fig. 4) 09.23.00-2 through 09.23.00-10 contain C. meyeriana (=Gliscopollis meyeriana). Samples 09.23.00-7 and 09.23.00-9 contain diverse assemblages of Late Triassic age. Species recovered from 09.23.00-7 and 09.23.00-9 include Alisporites parvus, Vitreisporites pallidus and Klausipollenites gouldii. In addition, 09.23.00-9 contains P. densus, Classopollis torosa, and Carnisporties spiniger. Sample 09.23.00-10 also contains $P$. densus, in addition to A. parvus and C. glismeyeriana. Based on the co-existence of $P$. densus and $C$. torosa and the overwhelming dominance of bisaccates species (primarily A. parvus), sample 09.23.00-9 is assigned to the Late Triassic (Rhaetian). Continued presence of $P$. densus and dominance of bisaccates in sample 09.23.00-10 indicate a Triassic age. Sample 09.23.00-11 is distinctly different in that it is dominated by Classopollis spp. (particularly $C$. meyeriana), and lacks $P$. densus. Based on the abundance of Classopollis spp. and the lack of any Triassic index species, this sample is assigned to the basal Jurassic. Sample 09.23.00-4 is also dominated by C. meyeriana and $C$. toros $a$ and lacks Triassic index species, but since $P$. densus appears in several of the overlying samples, 09.23.00-4 is Late Triassic. Hence, the boundary is placed between 09.23.00-10, which contains the highest occurrence of $P$. densus, and 09.23.00-11, which lacks $P$. densus or abundant bisaccates. Our new analysis differs from Fowell and Traverse (1995) in that C. meyeriana is abundant in one sample (09.23.00-11), attributable to our denser sampling. This addition strengthens the similarity between the Fundy and Newark basin T-J palynological transitions.

\subsection{Trends in eastern North America}

In terms of both the biotic and cyclostratigraphic characteristics, the most distinctive CAMP-associated strata are those directly below and above the HTQ basalt flows. These strata contain the T-J palynological turnover event, and the cyclicity exhibits an intensification of the pattern seen in Rhaetian strata in the same basins. Strata immediately above the HTQ basalts include abundant carbonates, a rare feature in other Jurassic sequences of eastern North America.

Beginning at the T-J palynological turnover level and extending into the overlying HFQ flows (where present), there is a dramatic increase in the frequency of well-preserved megafossil ferns, particularly the dipterid Clathropteris meniscoides. The spike in fern spore abundance at the T-J palynological turnover event in the Newark basin is dominated by the spores Converrucosisporites cameronii and Granulatisporites infirmus (Fowell et al., 1994), which are produced by $C$. meniscoides (Cornet and Traverse, 1975; Whiteside et al., 2003). In the Fundy basin, Clathropteris is present in the Scots Bay Member, but the fern Cladophlebis is the sole identifiable plant at the T-J palynological turnover event. In fact, it is the only identifiable plant genus in the entire Blomidon Formation (Olsen et al., 2002b).

We suspect that this interval, estimated at $300 \mathrm{ky}$ by cyclostratigraphy, of abundant carbonates and apparent fern acme maintained across a strong climate gradient of $\sim 9^{\circ}\left(16-25^{\circ} \mathrm{N}\right.$ palaeolatitude, Kent and Tauxe, 2005), from the relatively humid tropics to the arid subtropics, may be related to the initial phase of global warming. A two- to three-fold increase in $\mathrm{CO}_{2}$ associated with a $\sim 3-4^{\circ} \mathrm{C}$ temperature increase is inferred from rapid stomatal density reduction and plant physiognomy at the florally identified T-J boundary in Greenland and Sweden (McElwain et al., 1999; Royer et al., 2001; Beerling and Berner, 2002). We conclude that the entire complex thus represents a suite of boundary phenomena of timestratigraphic significance.

\section{CAMP and the T-J boundary in Morocco}

Late Triassic-Early Jurassic strata crop out over large portions of northern Morocco, comprising several sedimentary basins now partly dismembered by the subsequent Alpine orogeny. The palaeolatitude of these basins in earliest Jurassic coordinates was centered in arid climes around $23^{\circ} \mathrm{N}$. These basins have facies broadly similar to the Fundy basin but also show some similarities to the Triassic age sequences of the Newark basin. There is, however, a strong west-to-east trend from continental to marine facies. In western Morocco, beds above and below the oldest basalt flows have continental facies comparable to those in the Fundy basin outcrops. To the northeast, a shift towards more marine facies occurs; in easternmost Morocco, fully marine, mollusk-bearing limestones surround the basalt flows. 
Here, we will focus on two well-exposed basins representing continental facies typical of Morocco. From west to east, these are the Argana basin and the Central
High Atlas basin. Basalt flows supposedly predating the T-J boundary have been observed in sections from both basins (Marzoli et al., 2004; Knight et al., 2004).

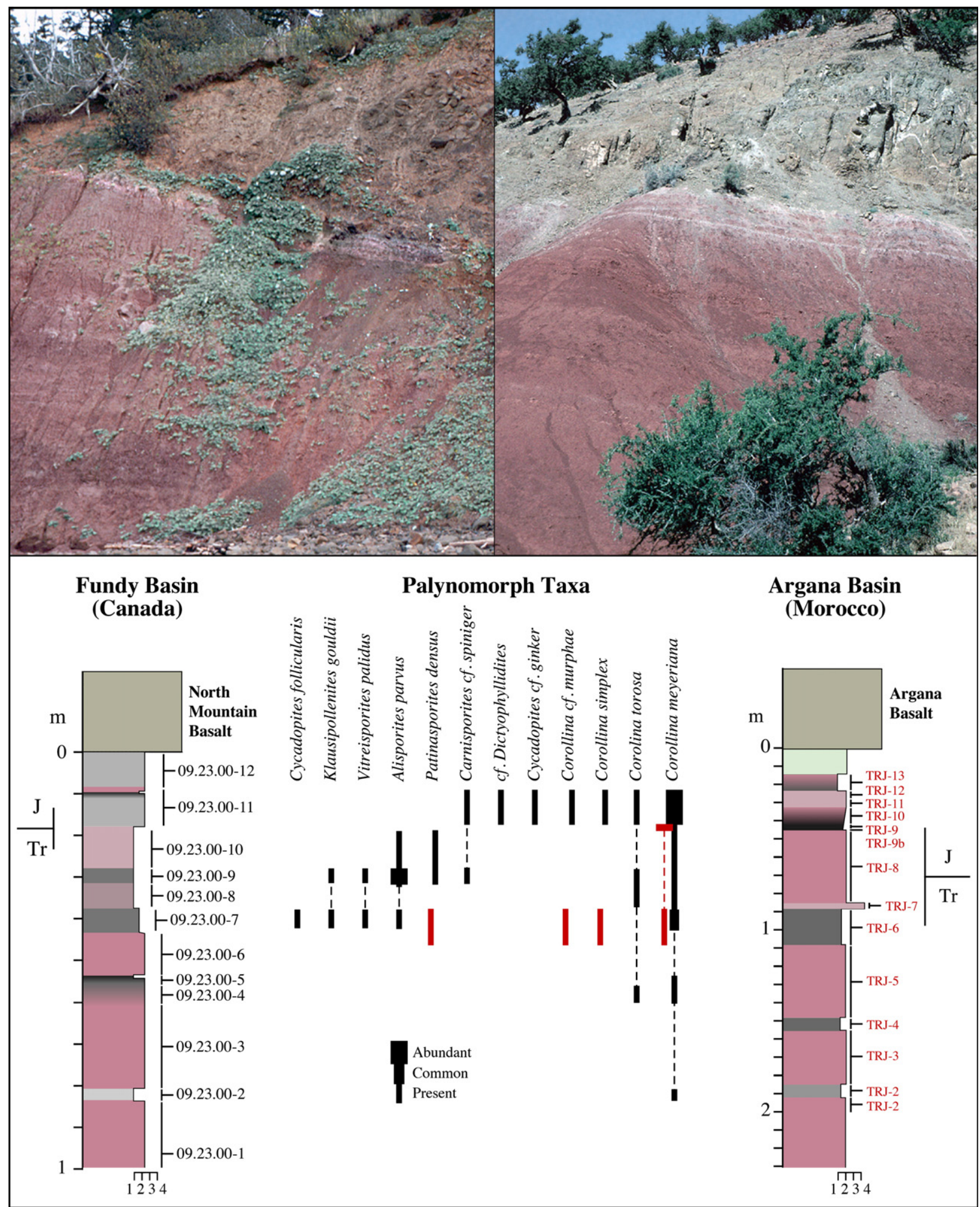




\subsection{Argana Basin}

The best studied basin in Morocco is the Argana basin northeast of Agadir (Tixeront, 1973; Olsen et al., 2000) $\left(22^{\circ} \mathrm{N}\right.$ palaeolatitude; Kent and Tauxe, 2005). The T-J palynological turnover event has been identified in the uppermost Bigoudine Formation below the Argana Basalt (Figs. 3A,B, 4). The HTQ-type Argana basalt is overlain by a thin carbonate unit with evaporite pseudomorphs (Olsen et al., 2002b) followed by a cyclical red and minor gray sequence (Hofmann et al., 2000).

In contrast to our interpretations, Marzoli et al. (2004) argue that the sections from the uppermost Bigoudine of the Argana basin have no Jurassic-age strata. They report rare $P$. densus (" $0-5$ " grains) from samples less than $5 \mathrm{~cm}$ below the basalt at their Aguersouine locality. The contact with the basalt, however, is highly deformed (Fig. 1, suppl. material of Marzoli et al., 2004), and the uppermost parts of the sedimentary strata may be structurally omitted. Alternatively, the rare $P$. densus grains may represent reworking. In contrast, the Argana locality described and figured in Olsen et al. (2002b) and the source of the palynological data has a virtually undeformed contact with the basalt, a recognizable, albeit thin metamorphosed zone, and underlying strata with Jurassic aspect palynomorphs (Fig. 4).

Apart from being less palyniferous, the Argana section is remarkably similar to the boundary section at Partridge Island in the Fundy basin (Olsen et al., 2000, 2002b) (Fig. 4). Sample TRJ-6 contains multiple grains of $P$. densus in addition to abundant $C$. meyeriana and Corollina murphyae. Samples TRJ-9b and TRJ-9a contain $C$. meyeriana. As these assemblages are thermally mature, further oxidation may reveal additional species of Corollina (e.g., C. torosa). Triassic index species have not been recognized in these samples, and consequently TRJ$9 \mathrm{a}$ and $\mathrm{b}$ are assigned to the Jurassic. We consider the disappearance of Triassic index species (e.g., P. densus) to denote the basal Jurassic in the Argana basin as in the homotaxial Fundy sections (Fig. 4).

\subsection{Central High Atlas basin}

Triassic and Jurassic strata of the Central High Atlas basin $\left(23^{\circ} \mathrm{N}\right.$ palaeolatitude; Kent and Tauxe, 2005) are exposed over a broad area in the High Atlas Mountains.
As in the Fundy and Argana basins, there is a package of cyclical gray, black and red strata below the oldest basalt. This is succeeded by the thickest basalt sequence in all of Morocco, which occupies more than $250 \mathrm{~m}$ of numerous individual flows. Tholeiites cluster into four geochemically definable, multiple flow formations termed the lower unit, the intermediate unit, the upper unit, and the uppermost recurrent flow (Bertrand, 1991). The lower unit, the intermediate unit, and the upper unit are of HTQ composition (Olsen et al., 2002b; data in Marzoli et al., 2004, and Knight et al., 2004). The recurrent flow is of HFTQ composition (data in Marzoli et al., 2004; Knight et al., 2004). No HFQ or LTQ flows have been identified. Marzoli et al. (2004) and Knight et al. (2004) demonstrate that the ${ }^{40} \mathrm{Ar} /{ }^{39} \mathrm{Ar}$ ages of these basalt flows are indistinguishable from their North American counterparts.

Bertrand (1991) followed by Marzoli et al. (2004) recognize an evolutionary geochemical sequence in these flows from $\mathrm{SiO}_{2}$ - and $\mathrm{TiO}_{2}$-rich lower basalts to $\mathrm{SiO}_{2}$ - and $\mathrm{TiO}_{2}$-poor upper basalts and very high $\mathrm{TiO}_{2}-$ but low $\mathrm{SiO}_{2}$-content recurrent basalts. Trace elements also show a distinctive pattern through the sequence. In particular, chondrite-normalized $\mathrm{La} / \mathrm{Yb}$ (Boynton, 1984) ratios are high in the lowest basalts and progressively decline in the upper basalts (Fig. 5). Marzoli et al. (2004) argue that the geochemical evolution of the Central High Atlas sequence differs from that of the Newark and Hartford basins, in that the lower and intermediate basalt units have higher silica and chondrite normalized $\mathrm{La} / \mathrm{Yb}$ ratios (Boynton, 1984) than any of the Newark and Hartford flows possess (Fig. 5). This is their primary geochemical evidence that the lower and intermediate flows are older than the oldest flows in North America. However, there is no discussion of published data from the more proximate Fundy basin that are inconsistent with their hypothesis (see below).

The lowest sedimentary strata in this CAMP sequence is a thin limestone interbed within the intermediate basalt (Marzoli et al., 2004; Knight et al., 2004) or between the lower and intermediate basalts (lower sedimentary interbed of Bertrand, 1991). A thicker limestone unit occurs between the intermediate and the upper basalt units (upper sedimentary interbed of Bertrand, 1991). An upper, cyclical, red and gray limestone and clastic unit is located between the upper and recurrent flows (Fig. 3A).

Fig. 4. Above: photograph of boundary sections at Partridge Island, Nova Scotia, in the Fundy basin (left) and the Argana basin (near Argana, Morocco; $\mathrm{N} 30^{\circ} 46.42^{\prime}, 009^{\circ} 09.10^{\prime}$ ) on the right. Boundary beds are the light coloured lines at the top of the red bed interval. Photo of Partridge Island covers about $18 \mathrm{~m}$ of section on the right hand side. Photo of Argana boundary section covers about $27 \mathrm{~m}$ on left side of the photo. Below: measured sections of boundary intervals from $\left(\mathrm{N} 30^{\circ} 46.65^{\prime}, 009^{\circ} 09.13^{\prime}\right)$ the above outcrops showing the distribution of the palynomorph taxa. Black represents the Fundy basin section (at Partridge Island). Red represents data from the Argana section. 


\section{Basalts of the Newark, Central High Atlas, and Fundy Basins}
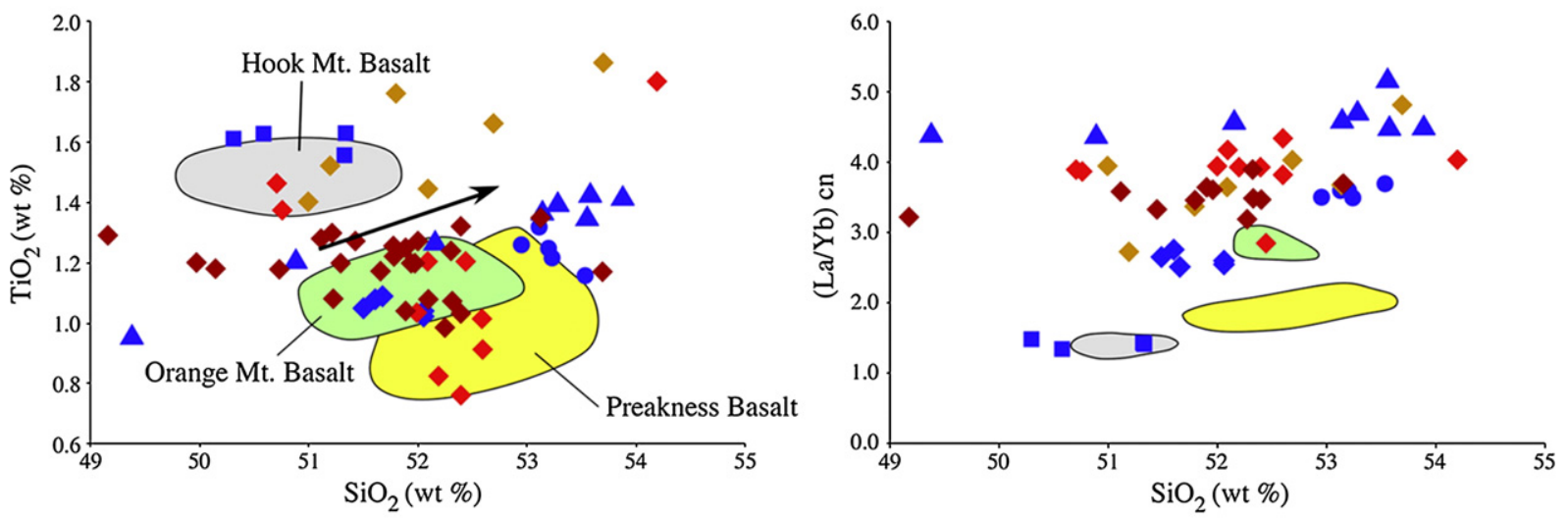

Moroccan Basalts

(Marzoli et al., 2004)

Nova Scotian Basalts

- Recurrent

- Upper

$\checkmark$ Intermediate

$\Delta$ Lower
- North Mt. Basalt (north shore) (Greenough, et al., 1989)

- North Mt. Basalt (Dostal \& Greenough, 1992)

- North Mt. Basalt (pegmatites) (Dostal \& Greenough, 1992)

Fig. 5. Aspects of the geochemistry of the Newark basin and Moroccan basalts showing the similarity between the North Mountain Basalt (red, orange, and yellow) and the lower and intermediate basalts of Morocco.

The recurrent flow is overlain by a cyclical, predominantly red clastic and evaporite sequence.

Previous palaeomagnetic studies of Moroccan basalts recovered only normal polarities (Marzoli et al., 1999; Olsen et al., 2003a). Marzoli et al. (2004) also found only normal polarities in the 33 lava flows sampled in the 260m-thick continuous volcanic pile at Tiourjdal. On the south flank of the Central High Atlas, however, they did identify magnetizations of apparent reverse polarity in the lower portion of the thin $(\sim 1 \mathrm{~m}$ thick) local limestone interbed within the intermediate basalt units in the section. Knight et al. (2004) recognize an additional very thin interval of reverse polarity spanning the top of one flow and the pillowed base of a succeeding flow (Fig. 2) at the base of the intermediate unit in the Oued Lahr section on the opposite side of the Central High Atlas. Noting that the demarcation of the lower and intermediate flow units is based on geochemistry, Knight et al. (2004) argue that these two reverse intervals may represent different polarity zones. These thin reverse polarity zones are critical because they could allow high-resolution correlation between the Central High Atlas CAMP and the Newark basin geomagnetic polarity time scale. The MarzoliKnight hypothesis posits that one or both of the thin reverse polarity zones correlates to the E23r chron of the Newark basin, and therefore, the lower unit and part of the intermediate unit are Triassic in age. We disagree with this correlation based predominantly on our interpretation of the cyclical lacustrine strata within and surrounding these flows and the presence of previously published reports of thin earliest Jurassic reverse polarity zones in marine strata of Europe and Great Britain, as described below.

One to three metres of cyclical, gray, black, and red mudstone are present directly below the lowest basalt in almost all Moroccan basins including the Central High Atlas basin (Fig. 3A). Some of these beds have total organic contents in excess of $2 \%$ and contain wellpreserved palynomorphs (Lab Facilities of the ONHYMRabat, Majid Elouataoui, personal communication, 2003). According to Marzoli et al. (2004), all of the palyniferous layers below the basalts contain $P$. densus and are therefore Triassic in age, and by inference, at least some of the overlying basalts are Triassic in age. The sections sampled, however, are evidently also deformed (e.g., Marzoli et al., 2004, Fig. 2), and we would argue that Jurassic strata could be again structurally omitted. In addition, their youngest palyniferous sample, derived from the sedimentary unit above the upper basalt unit, contains rare P. densus. Marzoli et al. (2004), however, argue that the presence of the $P$. densus in their youngest sample cannot constrain the age of the underlying basalt because it could be reworked. Hence, we argue that reworking is also a possibility for the rare grains of $P$. densus in some older strata (i.e., at Alemisi, in the Argana basin), and perhaps also in the uppermost sedimentary strata below the basalt in the Central High Atlas basin. 
Lithologically and cyclostratigraphically, the strata below the lowest basalt flows in the Central High Atlas basin are similar to the homotaxial units in the Argana and Fundy basins that we argue contain the T-J palynological turnover event. Given that any Jurassic strata in the pre-basalt interval is predicted to be less than $1 \mathrm{~m}$ thick, structurally uncomplicated sections need to be identified, documented, and sampled before it can be assumed that Jurassic strata are indeed absent.

\section{Correlation of the eastern North American and Moroccan basalts and adjacent strata}

Our initial hypothesis was that the homotaxial relationship between the CAMP basalts and associated strata in the eastern North American basins, the Argana basin, and the Central High Atlas basin indicates temporal correlation (Fig. 3A,B). This would predict that the T-J palynological turnover event should be below but close to the oldest HTQ basalt and the carbonate sequences should be correlative in all basins. The alternate Marzoli-Knight hypothesis predicts that the T-J palynological turnover event should fall within or overlie the Moroccan basalt flows, based on their correlation of thin, syn-basalt reverse magnetic polarity zones in the Central High Atlas basin with E23r in the uppermost Triassic age strata of the Newark basin. They argue that this correlation is supported by basalt geochemistry and the lack of palynologically identified syn-basalt Jurassic sedimentary strata in Morocco. Below, we discuss the evidence for correlation between the eastern North American and Moroccan CAMP flows and their relationship to the boundary.

\subsection{Physical and Cyclostratigraphy}

A strong degree of homotaxiality exists between the lithostratigraphy of the CAMP-bearing strata of eastern North America, especially the Fundy basin, and the Moroccan Argana and Central High Atlas basins (Fig. 3A,B). We argue that this homotaxiality that extends to details of the cyclostratigraphy and palaeontology indicates time correlation because of regional climatic control. We discuss three key intervals: (1) the T-J palynological turnover event as recorded in the Fundy and Argana basins; (2) the base of the entire basalt sequence; and (3) the Scots Bay Member of the McCoy Brook Formation of the Fundy basin and correlative strata in eastern North America, and the carbonate-rich sequences in the CAMP flows of Morocco.

There have been two attempts to use the cyclostratigraphy of the sedimentary rocks underlying, interbedded with, and overlying CAMP basalt flows to correlate amongst the basins and estimate the duration of the extrusive event. Olsen et al. (1996b) correlated curves of depth ranks (a semi-quantitative index of relative water depth) to a curve of the Quaternary precession index (154-1635 ky BP) and estimated the duration of the entire CAMP sequence to be $\sim 580 \mathrm{ky}$. Olsen et al. (2003a) followed a nearly identical procedure for the Newark and Moroccan Argana and Khemisset basins, leading to the additional conclusion that the T-J palynological turnover event lies below the oldest CAMP in Morocco. Here we use new data from cores and outcrops in the Newark, Hartford, Deerfield, Argana, and Central High Atlas basins and a new target curve (Fig. 3B) more appropriate for the T-J to provide a more precise correlation of lacustrine cycles on the conjugate rifted margins. We note that the approximately 600 ky duration of the CAMP lava flows derived from the cyclostratigraphy of Olsen et al. (1996a,b) was corroborated by the independent ${ }^{40} \mathrm{Ar} /{ }^{39} \mathrm{Ar}$ dates of Hames et al. (2000) and Marzoli et al. (2004) that are analytically indistinguishable from each other.

Our revised cyclostratigraphy incorporates new data from the Silver Ridge B-1 core that penetrates the lower half of the very early Jurassic Shuttle Meadow Formation and the underlying HTQ Talcott Formation of the Hartford basin (Fig. 3B). Together with outcrop sections, this core permits construction of a new composite section through the entire Shuttle Meadow Formation (Fig. 3A) and a revision of the cyclostratigraphy of the correlative section in the Newark basin. Correlation between the Silver Ridge B-1 core and the Feltville Formation (Martinsville no. 1 and Army Corps of Engineers ACE cores) (Olsen et al., 2003a) demonstrates that the lower Feltville Formation as recovered in the Martinsville no. 1 core is a condensed section, missing one full precession cycle. Lacking the Silver Ridge B-1 core, Olsen et al. (1996b) slightly overestimated the duration of the upper Feltville Formation, underestimated the time represented by the thickness of the overlying HFQ flows, and underestimated the duration (and number of cycles) in the lower part of the formation. Although the ACE cores from the more northern part of the Newark basin sampled a more expanded, and in hindsight, complete section of the lower Feltville Formation, they did not allow compilation of an unambiguous complete section of the entire Feltville Formation; consequently, they were not used by Olsen et al. (1996b, 2003a). Correlation of the Feltville Formation with the new composite section through the Shuttle Meadow Formation now allows the ACE data to be used as a basis for the cyclostratigraphy of the Feltville Formation. Our new cyclostratigraphy (Fig. 3B) demonstrates that the flows of the Preakness Basalt represent $\sim 80 \mathrm{ky}$. 
The aggregate changes from Olsen et al. (2003a) are mostly compensatory resulting in only a slightly revised total duration of CAMP activity now estimated at $\sim 610 \mathrm{ky}$.

To facilitate discussion, we introduce a nomenclature for the cyclostratigraphy based on division of the sections into $\sim 100 \mathrm{ky}\left(\mathrm{E}_{100}\right)$ and $\sim 400$ years $\left(\mathrm{E}_{400}\right)$ cycles. The boundaries of these cycles are positioned at the correlative precessional minima of the new target curve (Fig. 3B). Using this nomenclature, the T-J palynological turnover event in the Newark Supergroup lies within cycle $\mathrm{E}_{100} 1$, deposited during times of high eccentricity and high climatic precession amplitude. In Olsen et al. $(1996 a, b)$ the palynological turnover event was correlated to an interval of low precession index on the target curve. In the new correlation the palynological turnover event is shifted down one precession cycle relative to the target curve. In turn, cycle $\mathrm{E}_{100} 1$ is near the peak of a $\sim 400 \mathrm{ky}$ cycle (cycle $\mathrm{E}_{400} \mathrm{JH} 1$; Fig. 3B). The presence of only very thin red and discontinuous sedimentary strata between flows shows that the earliest set of basalt flows in the Newark basin (HTQ Orange Mountain Basalt) were extruded during a time of relatively shallow lake development, most parsimoniously within a $\sim 100$ ky cycle precessional minimum. The overlying red, gray and black limestone-bearing sequences of the lower Feltville Formation were deposited during the next peak of a $\sim 100$ ky cycle (cycle $\mathrm{E}_{100} 2$ ) within the same $400 \mathrm{ky}$ cycle as the T-J palynological turnover event (cycle $\mathrm{E}_{400} \mathrm{JH} 1$ ) (Fig. 3B). The primarily red clastic sequence of the upper Feltville Formation was deposited during a minimum in the 400 ky cycle $\left(\mathrm{E}_{100} 3\right.$ and $\mathrm{E}_{100} 4$; Fig. $\left.3 \mathrm{~B}\right)$, as were the Preakness Basalt (HFQ) and interbedded red clastic rocks. The next well-developed red, gray and black sequence of the Towaco Formation was deposited during a peak in the succeeding $400 \mathrm{ky}$ cycle, cycle $\mathrm{E}_{400} \mathrm{JH} 2$ (Fig. 3B). This is mirrored closely by the cyclostratigraphy of the Hartford basin (Fig. 3B).

The Fundy basin cyclostratigraphy is most parsimoniously interpreted as a stratigraphically condensed expression of $\mathrm{E}_{100} 1$ of $\mathrm{E}_{400} \mathrm{JH} 1$ (Fig. 3B), relative to what is seen in the Newark and Hartford basins. Magnetostratigraphic correlations indicate that the overall accumulation rate in the Fundy basin is about $18 \%$ that of coeval Newark basin sequences (300 vs. $1700 \mathrm{~m}$ in $11.5 \mathrm{my}$ ) (Kent and Olsen, 2000). As in the Newark basin, the T-J palynological turnover event lies within a red, gray, and black sequence with well-developed cyclicity. Assuming that these thin $(<20 \mathrm{~cm})$ cycles correspond to the precession cycles in the Newark basin, the accumulation rate in this interval is $2 \%$ of that of the Jacksonwald Syncline section $(0.01 \mathrm{~m} / \mathrm{ky}$ vs. $0.58 \mathrm{~m} / \mathrm{ky})$, consistent with the independent graphic correlation between the magnetostratigraphies of the two basins (Olsen et al., 2005). Given that the T-J palynological turnover event is present in the uppermost Blomidon Formation, these cyclical strata just below the North Mountain Basalt should represent the peak of cycle $\mathrm{E}_{100} 1$ of $\mathrm{E}_{400} \mathrm{JH} 1$. Likewise, the very sporadic and thin sedimentary strata between the North Mountain HTQ flows are entirely red mudstone, probably of basaltic origin, deposited during a minimum in the $\sim 100$ ky cycle. The overlying Scots Bay Member of the McCoy Brook Formation thus correlates with the maximum of cycle $\mathrm{E}_{100} 2$, still within the peak of $\mathrm{E}_{400} \mathrm{JH} 1$. The directly overlying red lacustrine and eolian strata lie within the trough of that $400 \mathrm{ky}$ cycle.

In Morocco, the cyclical red, gray, and black strata just below the Argana Basalt of the Argana basin and the lower basalt flow unit of the Central High Atlas basin were deposited during $\mathrm{E}_{100} 1$ of $\mathrm{E}_{400} \mathrm{JH} 1$. We interpret the condensed limestone interval above the Argana Basalt as strata deposited during the peak of cycle $\mathrm{E}_{100} 2$ also in the peak of $\mathrm{E}_{400} \mathrm{JH} 1$. The succeeding $20 \mathrm{~m}$ of red mudstone and sandstone were deposited during the trough of a $405 \mathrm{ky}$ cycle, and the overlying, cyclical red and gray strata in the Argana basin were deposited during the peak of $\mathrm{E}_{400} \mathrm{JH} 2$ (Fig. 3B).

The picture is more complex in the Central High Atlas basin. We argue that the intermediate and upper basalts were deposited during the peak of cycle E1002 based on the presence of lacustrine limestones indicating wetter environments than red clastics, that are present between the lower and intermediate basalts, within the intermediate basalt, between the intermediate and upper basalts, and on the top of the upper basalt (Bertrand, 1991; Marzoli et al., 2004; Knight et al., 2004). As in the Argana basin, cyclical red and gray strata above the limestones but below the recurrent basalt unit suggest deposition during the peak of $\mathrm{E}_{400} \mathrm{JH} 2$ (Fig. 3B). In this cyclostratigraphic correlation (Fig. 3B) the lavas of the intermediate and upper basalt units of the Central High Atlas were extruded during deposition of the Scots Bay Member and its equivalents in the more southern basins (in $\mathrm{E}_{100} 2$ of $\left.\mathrm{E}_{400} \mathrm{JH} 1\right)$. This implies a very short duration ( $\left.<40 \mathrm{ky}\right)$ for the extrusion of these lavas, and it assumes that the limestone units were deposited during a time of high eccentricity favorable to their production.

Chron E23r falls within the $\mathrm{E}_{100} 1$ precessional maximum. Assuming the Marzoli-Knight hypothesis to be correct, cyclostratigraphic correlation suggests that there should be only two thin black-gray and red cycles (precession cycles) below the basalts. Instead, the pre-basalt Argana and Central High Atlas basin sections contain five black-gray and red cycles corresponding to the peak of a $\sim 100$ ky cycle (Fig. 3A) as in the Newark and Fundy basins, suggesting that the Moroccan basins 
contain the full cyclostratigraphic equivalents of the prebasalt sections in their North American counterparts.

\subsection{Basalt geochemistry}

In support of their hypothesis, Marzoli et al. (2004) argue that geochemical trends through the High Atlas sequence indicate that the lower and intermediate units are older than the oldest basalts in the Newark and Hartford basins despite that they are HTQ basalts, chemically similar to the Newark basin Orange Mountain Basalt (Olsen et al., 2003a) and its counterparts in the Hartford and Culpeper basins. In particular, Marzoli et al. (2004) show that the lower unit of Morocco has higher silica and chondrite normalized $\mathrm{La} / \mathrm{Yb}$ (Boynton, 1984) ratios than any of the Newark and Hartford flows (Fig. 5). Marzoli et al. (2004) argue that because the T-J boundary is so close to the base of the Orange Mountain Basalt, the lower unit of the Central High Atlas sequence could predate the boundary. They argue that this is an evolutionary trend, caused by a temporal sequence of magmatic events that can be used to correlate laterally. The North Mountain Basalt of the Fundy basin, however, is much closer geographically to the High Atlas basin than it is to the Newark or Hartford basins (Figs. 1, 3A). Thus, it might be expected to be more geochemically similar to Moroccan basalts, which proves to be the case. The silica content and chondrite normalized $\mathrm{La} / \mathrm{Yb} \mathrm{cn}$ ratios of the North Mountain Basalt overlap those of the Central High Atlas lower unit (Fig. 5). Based on the geochemical methodology of Marzoli et al. (2004), the North Mountain Basalt could correlate with at least the lower basalt unit of the Central High Atlas series. However, the T-J palynological turnover event and associated vertebrate extinctions are represented in the strata immediately below the North Mountain Basalt (Fig. 4), which is in obvious conflict with their hypothesis.

We hypothesize that the high $\mathrm{La} / \mathrm{Yb}$ cn ratios of the North Mountain and initial Central High Atlas basalt are a consequence of crustal contamination derived from longdistance lateral transport from dikes emanating from then adjacent regions of the southeastern United States and Senegal. This hypothesis is supported by magnetic anisotropy data of Ernst et al. (2003) and de Boer et al. (2003) who argue for lateral transport of magma over distances of $1000 \mathrm{~km}$. We hypothesize that the Orange Mountain Basalt and its correlatives in the southeastern and northeastern United States are contemporaneous with the lower and intermediate flows in the Argana and Central High Atlas basins, and that the lower $\mathrm{La} / \mathrm{Yb}$ cn ratios are a consequence of erupting closer to the source of the magma, which de Boer et al. (2003) suggest was in the Blake Plateau region (Fig. 1). We argue, however, that most of the major element chemistry of these basalts can still be used for correlation (e.g., Olsen et al., 2003a).

\subsection{Magnetostratigraphy}

The crux of the Marzoli-Knight hypothesis is the correlation of one or two reverse magnetic polarity units found within the Central High Atlas basalts with chron E23r of the Newark basin. In Marzoli et al. (2004), only one reverse polarity zone is described from within a white limestone near the middle of the intermediate basalt flow unit (Fig. 2) and correlated with Newark basin chron E23r. In Knight et al. (2004), however, two reverse polarity zones are described, each from a different section. The upper one is the same, but not independently determined, as that described in Marzoli et al. (2004); the additional lower one is at the base of the intermediate unit. Both of these reverse polarity intervals are ambiguously correlated to chron E23r (Fig. 2). In neither paper, however, are these correlations tested by examination of the magnetostratigraphy of the strata underlying the basalts, which, according to our hypothesis should contain a reverse polarity zone correlative to chron E23r, unless structurally omitted.

Rather than correlatives of chron E23r, these two reverse polarity intervals, if not artifacts of remagnetization, may represent earliest Jurassic intervals of reverse polarity not sampled in the Newark basin sequence. Independent evidence of brief Early Hettangian reverse intervals exists in the form of 3 thin reverse polarity zones (Yang et al., 1996) in the basal marine Hettangian section of the Moncornet core from the Paris basin (Fig. 2). Lava flows provide spot readings of Earth's magnetic field behavior, and because many more flows (cooling units) are present in the Central High Atlas basalts than in the Newark basin even though it was relatively heavily sampled (Fig. 3A), it is quite possible that these Moroccan sections may preserve a more complete record of the field behavior. However, the North Mountain Basalt also has many more flows (Dostal and Greenough, 1992) than the basalt formations of the Newark and Hartford basins (Fig. 3A). Previous palaeomagnetic work on the North Mountain Basalt obtained stable magnetizations of only normal polarity (Carmichael and Palmer, 1968; Hodych and Hayatsu, 1988), as has been the case with all other Newark basin basalts (Hozik, 1992), although it is very unlikely that all or even most of the cooling units were sampled in outcrop. Thus, based on the number of flows present, one alternative to the MarzoliKnight hypothesis is that thin (i.e., short) reverse polarity intervals could be present in the as yet poorly sampled North Mountain Basalt. 
Another possibility is that the Central High Atlas reverse intervals may be present in the lower part of the Scots Bay Member of the Fundy basin, which has to our knowledge never been sampled, the lower parts of the Feltville Formation, sampled only where it is represented by a condensed section (i.e., Martinsville no. 1 core), or the lower Shuttle Meadow Formation, for which there are no published results. Clearly these sections need to be sampled in detail.

Intrusions of demonstrated CAMP affinity of reverse polarity are virtually unknown anywhere, but could potentially provide evidence of pre-T-J boundary CAMP activity. The only documented example from eastern North America is from a north-south-trending dike in North Carolina reported by Smith (1987; site 22) that is part of a dike swarm in the Carolinas with typical CAMP ages of $\sim 200 \mathrm{Ma}$ (e.g., Ragland et al., 1992). While Olsen et al. (2003a) regarded this dike as possible evidence of some CAMP igneous activity just prior to the T-J boundary (i.e., during chron E23r), our present interpretation suggests it might be recording one of the short events reported by Marzoli et al. (2004) and Knight et al. (2004) that we suggest are of post-Triassic age.

\subsection{Biostratigraphy}

Independent biostratigraphic data supporting our hypothesis come from strata above and interbedded with the CAMP basalts in the Fundy and Central High Atlas basins (Fig. 6). The Scots Bay Member, a distinctive carbonaterich lacustrine sequence of the basal McCoy Brook Formation, is locally very fossiliferous, containing a typical Early Jurassic-type palynoflora (Bujak, 1977; Bujak, cited in Olsen et al., 1987) and a distinctive dwarf mollusk assemblage (Good et al., 1994) comprised of bivalves and at least two species of gastropods: a low-spired form probably Valvata sp. and a high-spired form that probably represents a genus of the Hydrobiidae (Fig. 6). Red marginal lacustrine, fluvial, and eolian strata immediately above the Scots Bay Member have produced rich tetrapod assemblages and associated footprints lacking any taxa confined to the Triassic (Olsen et al., 1992) (Fig. 3B).

Lithologically and cyclostratigraphically similar to the Scots Bay Member of the Fundy basin, the locally well-developed carbonate sequence between the intermediate and upper basalt units of the Central High Atlas basin yields newly discovered hydrobiid gastropods

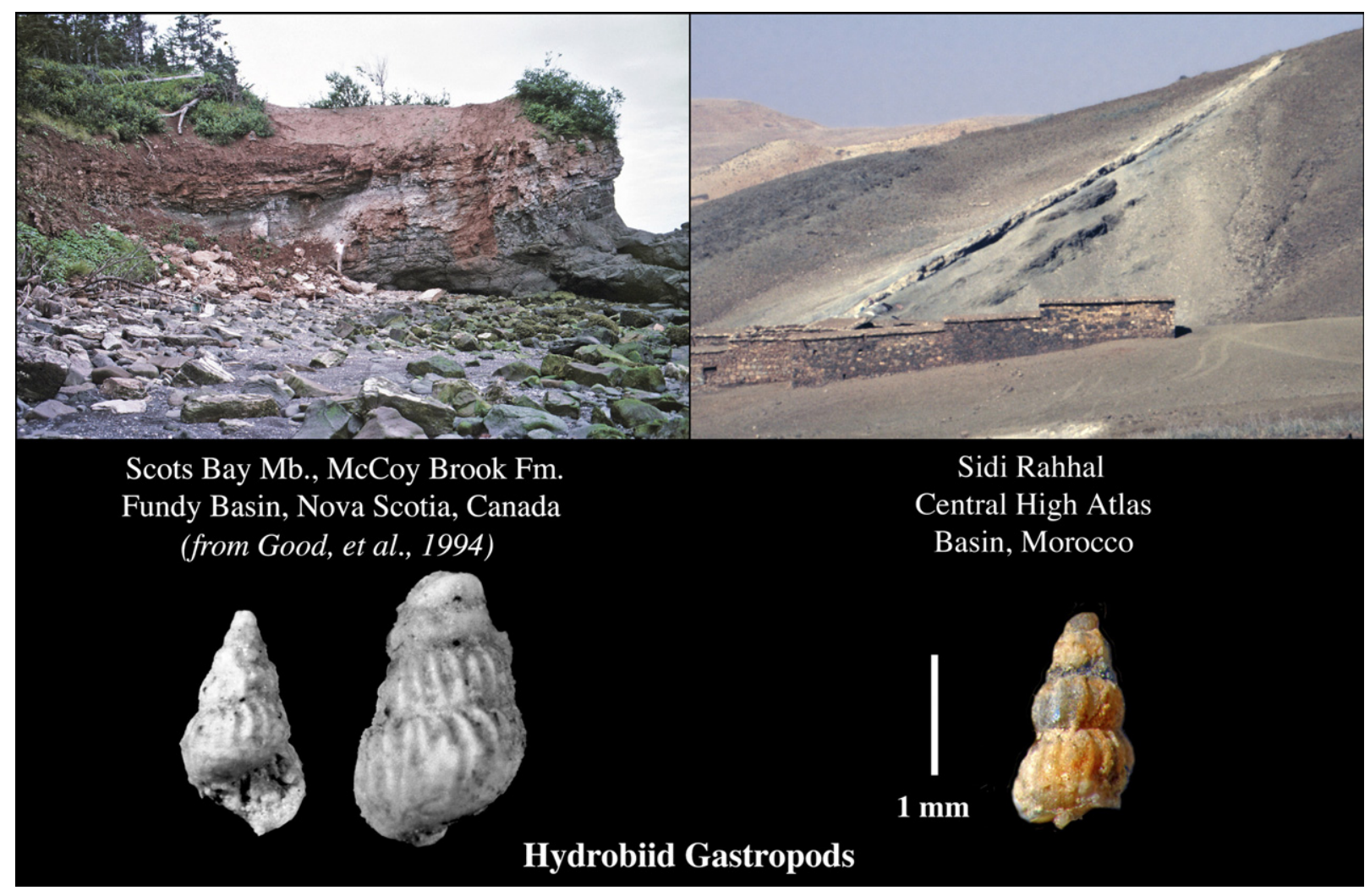

Fig. 6. Limestone sequences of the Scots Bay Member of the McCoy Brook Formation of the Fundy basin, Nova Scotia (left), and the limestone sequence between lower and upper basalt units in the Central High Atlas basin at Sidi Rahhal, Morocco and examples of their dwarf hydrobiid molluscs. 
indistinguishable from those from the Scots Bay Member (Fig. 6). These occurrences could represent the same unusual widespread coeval environmental conditions, controlled by climate, although we note they could represent similar facies rather than a biostratigraphic datum per se.

\section{Correlation to marine sections}

Anomalies in stable carbon isotope $\left(\delta^{13} \mathrm{C}\right)$ records from carbonate and organic matter potentially provide a powerful correlation tool between T-J marine (Morante and Hallam, 1996; McRoberts et al., 1997; Pálfy et al., 2001; Ward et al., 2001; Hesselbo et al., 2002; Guex et al., 2004; Ward et al., 2004; Galli et al., 2005; Huynh and Poulsen, 2005) and non-marine sections (cf., McElwain et al., 1999; Hesselbo et al., 2002). Existing data reveal a carbon cycle perturbation represented by one or two shifts to more $13 \mathrm{C}$ depleted values (up to $-3.5 \%$ ) associated with the palynological extinction horizon. Major carbon isotope decreases in marine or terrestrial records are mechanistically linked to increased atmospheric $\rho \mathrm{CO}_{2}$ acting through exchangeable reservoirs (cf., Kump and Arthur, 1999). For the T-J boundary, excursions to more $13 \mathrm{C}$ depleted values have generally been interpreted as a consequence of voluminous volcanogenic gas effusion or CAMP-triggered methane release from marine-continental margin gas hydrates. No direct data, however, demonstrate the temporal relationship of the excursions to CAMP emplacement because basaltic flows are present primarily in continental sections devoid of marine fossils, and marine sections tend to have few continental fossils. The one continental section in which an excursion has been demonstrated (Kap Stewart Formation, eastern Greenland; McElwain et al., 1999; Hesselbo et al., 2002,) is outside the area with CAMP lavas. Here we review the evidence linking the isotopic anomalies to CAMP sections.

Although also outside the CAMP lava area, the St. Audrie's Bay section in the Bristol Channel area of Great Britain (Hesselbo et al., 2002) currently provides the best link between the CAMP sections and carbon isotope anomalies. There, marine invertebrates and palynomorphs, including pollen and spores, are present. The magnetostratigraphy is documented (Hounslow et al., 2004), along with the chemostratigraphy, which includes bulk organic $\delta^{13} \mathrm{C}$ data and Os and Re isotopes (Hesselbo et al., 2002; Cohen and Coe, 2002) (Fig. 7).

Biostratigraphic ties to CAMP sections are provided by an interval of palynofloral change comparable to that seen in eastern North America (Hesselbo et al., 2002). In particular, the highest records of Ovalipollis and several other typically Triassic taxa occur in the Cotham Member of the Lilstock Formation of the Penarth Group, immediately above which Classopollis (Gliscopollis) meyeriana first becomes abundant. Although comprised of different taxa (Hounslow et al., 2004), an overlying diversification and peak abundance of spores is reminiscent of the Newark basin spike in fern spore abundance. Above the Lilstock Formation, in the Lias Group, Classopollis spp. is overwhelmingly dominant (50-90\%), similar to the Early Jurassic age assemblages in eastern North America.

The last occurrence of Ovalipollis is coincident with the lower, "initial" of two negative $\delta^{13} \mathrm{C}$ anomalies (Hesselbo et al., 2002). Another, stratigraphically thicker isotopic minimum, termed the "main isotope excursion" by Hesselbo et al. (2002), occurs higher in the Lias Group in association with the dominance of Classopollis spp. and the appearance of Jurassic ammonites. A similar pair of $\delta^{13} \mathrm{C}_{\text {org }}$ anomalies in bulk carbon have been recognized at several widely separated marine sections (Ward et al., 2004; Guex et al., 2004; Galli et al., 2005).

Unfortunately, the relationship between the palynological transition in the Lilstock Formation and the marine extinction horizon, particularly the last appearance of conodonts, is equivocal for two reasons. First, the St. Audrie's Bay section is characterized by a dramatic facies transition from non-marine red beds to fully marine limestones of the Lias Group, recording a marine transgression (see debate in Hesselbo et al., 2004a,b; Hallam and Wignall, 2004). In addition, Hounslow et al. (2004) regard the upper termination of the spore-rich interval as the more significant floral boundary. We note, however, that the decrease in spore diversity coincides with a strong facies change at the base of the Lias Group. Surely this facies change exerts some influence on the constituent palynoflora. No such facies change occurs at the T-J palynological turnover event in eastern North America. In addition, the transition marked by the last appearance of Ovalipollis and the initial $\delta^{13} \mathrm{C}$ excursion occur within the Lilstock Formation and not at a facies boundary, suggesting that these events may have more time significance than the overlying palynological change (Fig. 7).

Second, conodonts have not actually been found in the St. Audrie's Bay section. Their last appearances at other localities (Swift, 1995; A. Swift, quoted in Hounslow et al., 2004) have been correlated by Hounslow et al. (2004) to a level above the initial and below the main isotopic excursions in the upper Langport Member at St. Audrie's Bay. Hounslow et al. (2004) interpret this to mean that the palynofloral transition and initial isotopic excursion lie below the marine invertebrate extinction horizon (Hounslow et al., 2004; Guex et al., 2004). According to the correlation of Hounslow et al. (2004), the last appearance of conodonts should occur $15 \mathrm{~cm}$ below 
Newark

St. Audrie's Bay

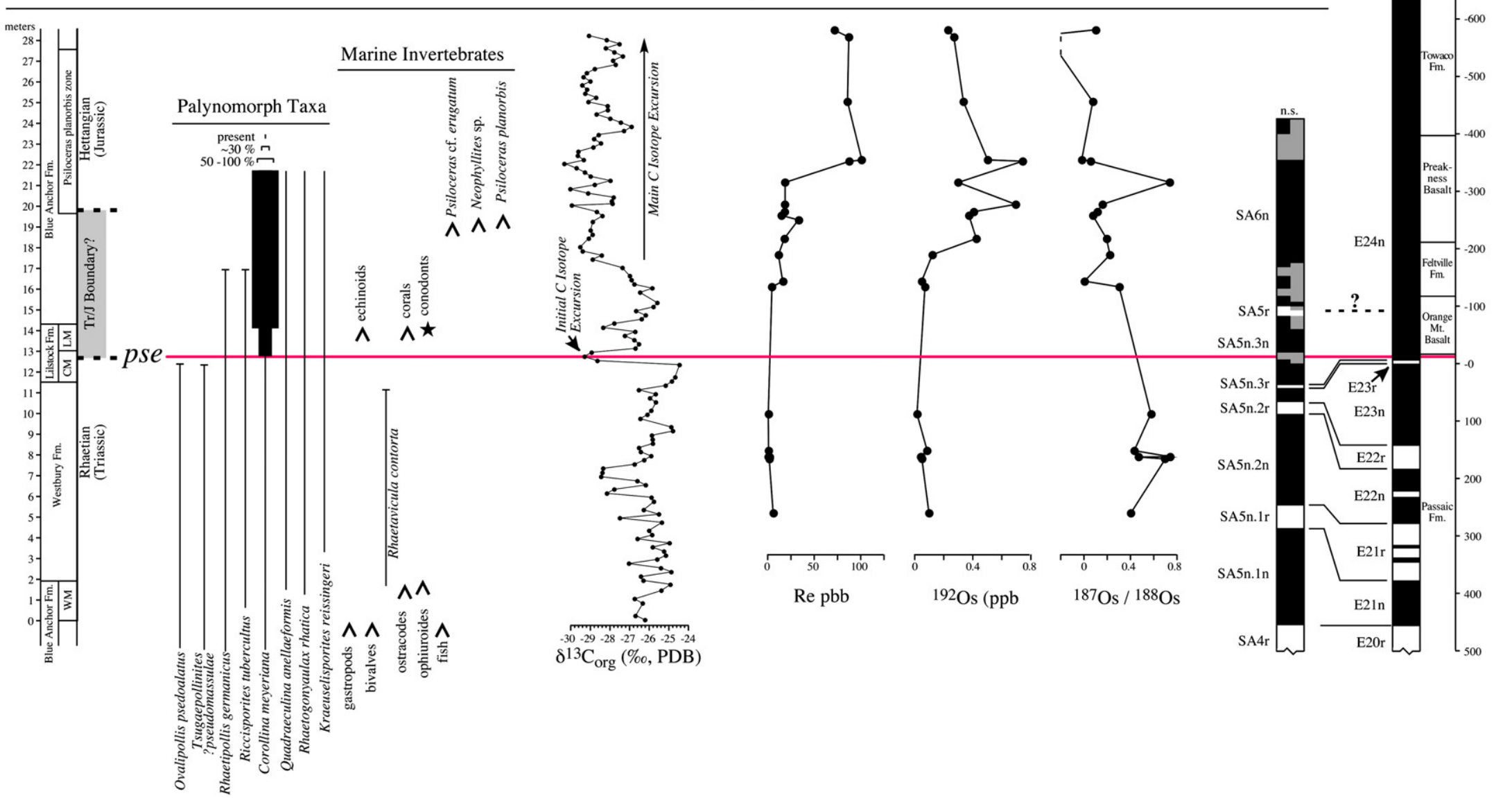

Fig. 7. Proposed correlation between the lithostratigraphy and biostratigraphy (Hounslow et al., 2004), $\delta^{13} \mathrm{C}_{\text {org }}$ (Hesselbo et al., 2002), Re elemental abundance and Os isotope (Cohen and Coe, 2002) chemostratigraphy, and magnetostratigraphy (Hounslow et al., 2004) of the St. Audrie's Bay section and the Newark basin section (Kent et al., 1995). The red line (pse) marks what we regard as the correlative palynological (pollen and spore) extinction level in the two sections. 
the top of the Lilstock Formation at St. Audrie's Bay, and therefore, they would be less than $1 \mathrm{~m}$ above the initial excursion within a $2.5 \mathrm{~m}$ thick formation. It may be that the last appearance of conodonts does post-date the initial isotopic excursion and the associated palynological change, or that the Lilstock Formation is time transgressive, or that the conodonts are reworked. Without additional sampling to test this correlation, it seems premature to conclude that the marine extinction level postdates the initial isotopic excursion and the palynological transition. All that can be said at present is that the last Triassic marine invertebrates are found close to the initial excursion, and it seems plausible that the latter correlates to the palynological turnover event in eastern North America.

The magnetostratigraphy of the lower part of the St. Audrie's Bay section is similar to that of the Middle Passaic Formation of the Newark basin (Briden and Daniels, 1999; Hounslow et al., 2004). Nevertheless, correlation between the latest Triassic and Early Jurassic portions of the St. Audrie's Bay section is much more ambiguous. Correlation of St. Audrie's Bay polarity zone SA5r to chron E23r of the Newark basin (Hounslow et al., 2004) places the initial isotopic anomaly of Hesselbo et al. (2002) prior to chron E23r (and thus, prior to the T-J palynofloral boundary in eastern North America). According to this scenario, none of the palynological changes seen in St Audrie's Bay would correlate with the palynological change in eastern North America. To reconcile resulting conflicts in the magnetostratigraphy between the underlying St. Audrie's Bay section and the Newark sequence, Hounslow et al. (2004) propose several unconformities and introduce one or more ad hoc major polarity intervals corresponding to the omitted sections. A more parsimonious interpretation of the highly condensed St. Audrie's Bay section is that the SA5n.3r and SA5n.4n polarity zones correlate with Newark basin chrons E23r and E24n. According to this scenario, magnetozones SA5n.2r and SA5n.3n correlate with chrons E22r and E23n, and magnetozones SA5n. $1 \mathrm{r}$ and SA5n.2n correlate with chrons E21r and E22n, respectively, and magnetozone SA5n.1n correlates with chron E21n (Fig. 2). In our interpretation, the SA5r polarity zone occurs within the interval of CAMP volcanism, including one of the reverse polarity intervals found by Marzoli et al. (2004) and Knight et al. (2004), and with one of the thin reverse Hettangianage intervals in the Paris basin core (Yang et al., 1996).

Additional evidence for correlation between the CAMP flows and marine strata comes from a distinctive shift in Re and Os elemental abundances and isotopes through the T-J boundary interval at St. Audrie's Bay (Cohen and Coe, 2002). ${ }^{192}$ Os begins to increase just above the Lilstock Formation, in the Hettangian pre-pla- norbis beds, and continues to increase upward, peaking near the base of the P. planorbis zone (Fig. 7). Re does not increase in concert, but remains relatively constant to the base of the P. planorbis zone, where it abruptly increases to a maximum. The ${ }^{187} \mathrm{Os} /{ }^{188} \mathrm{Os}$ ratio decreases dramatically between the top of the Westbury Formation and the bottom of the Lias Group, and Cohen and Coe (2002) interpret these data as results of an increase in the flux of basaltic weathering products to the oceans due to the onset of CAMP volcanism. If the palynological change in the middle of the Lilstock Formation does indeed correlate to the extinction horizon in eastern North America, the flux of CAMP weathering products would have been delivered to the oceans after the extinction event, consistent with our hypothesis of little or no preceding CAMP eruptions (Fig. 7).

Our correlation of the St. Audrie's Bay section and the CAMP-bearing sections in eastern North America (cf., Hesselbo et al., 2002), predicts that a correlative of the initial $\delta^{13} \mathrm{C}_{\text {org }}$ excursion should be present above E23r, at the palynological extinction event, and below the oldest CAMP basalts. Furthermore, it predicts that the main excursion should be recorded within strata interbedded with and possibly overlying the CAMP flows. Analysis of suitable sections in eastern North America is in progress (e.g., Whiteside et al., 2003) to establish the precise relationship between the isotopic shifts and CAMP flows and test correlations of marine and continental T-J boundary sections.

\section{Tests of the Marzoli-Knight and alternative hypotheses}

The Marzoli-Knight hypothesis makes chemo- and magneto-stratigraphic predictions that can be tested. First, it predicts that the High Atlas basalts were extruded during the carbon cycle perturbation reflected in the initial negative $\delta^{13} \mathrm{C}$ anomaly of Hesselbo et al. (2002) (Figs. 2, 7). While the evidence of such an excursion may be difficult to find because of limited sedimentary strata between the Moroccan flows, the hypothesis excludes the presence of such an excursion in the underlying supposedly Triassic strata. Second, it predicts that the CAMP flows and interbedded sedimentary strata in eastern North America should be entirely of normal polarity, which is consistent with our limited sampling thus far, and it predicts that the magnetostratigraphy of the strata underlying the Central High Atlas basalt sequence should lack an equivalent of chron E23r.

Our alternative hypothesis is that the Central High Atlas basalt sequence postdates the palynological extinction. Hence, the sedimentary rocks immediately below the 
extinction horizon should preserve the brief initial isotopic excursion, and sedimentary strata interbedded with the Central High Atlas basalts should preserve a record of the prolonged main isotopic excursion. The initial excursion should fall below the oldest HTQ basalts in eastern North America, and the equivalent of the reverse polarity intervals of Marzoli et al. (2004) and Knight et al. (2004) should be located within or directly above the eastern North American HTQ flows (e.g., in the North Mountain Basalt or Scots Bay Member). These specific and distinct predictions are directly testable by additional sampling and analysis.

\section{Conclusions}

A re-evaluation of rift basin cyclostratigraphy based on a synthesis of new stratigraphic data in eastern North America confirms previous results that restrict CAMP flows to strata that post-date the T-J palynological turnover event. The total duration of the CAMP event is $\sim 610 \mathrm{ky}$, representing a slight (upward) revision of previous estimates (cf., Olsen et al., 1996b).

Marzoli et al. (2004) and Knight et al. (2004) present evidence of reverse polarity intervals within CAMP flows and interbedded sedimentary strata of Morocco that they postulate predate the T-J palynological turnover event and, hence, the T-J boundary based on magnetostratigraphic and geochemical correlation to the Newark basin section. Our alternative to this MarzoliKnight hypothesis is that their reverse polarity intervals, if real, are actually of Hettangian age and should be present within either the Early Jurassic North Mountain Basalt of the Fundy basin or immediately overlying sedimentary strata or its equivalents elsewhere in eastern North America. These two hypotheses regarding correlation of the Moroccan and eastern North American CAMP sections to the T-J boundary generate divergent and testable chemostratigraphic predictions. According to the Marzoli-Knight hypothesis, the initial $\delta^{13} \mathrm{C}_{\text {org }}$ excursion seen in the St. Audrie's Bay section (Hesselbo et al., 2002) should be recorded within the CAMP flows of Morocco. If our hypothesis is correct, the initial $\delta^{13} \mathrm{C}_{\text {org }}$ excursion will fall below the oldest CAMP flow and be coeval with the palynological extinction.

\section{Acknowledgements}

Financial support came from the National Science Foundation (Graduate Research Fellowship to Whiteside; grant EAR-9814475 and EAR-9804851 to Olsen and Kent and EAR-0310240 to Kent and Olsen, Sigma Xi Grant in Aid of Research to Whiteside, and a grant from the Lamont Climate Center to Whiteside and Olsen. We gratefully acknowledge logistical support while in Morocco from ONHYM. We thank Steven Good for use of his images of Scots Bay Member gastropods and Nicholas McDonald for access to his extensive fossil collections. Peter Keleman, Steve Goldstein, and Philip Huber are appreciatively recognized for enlightening discussions on basalt and physical stratigraphy. We thank Dorion Sagan for reading the manuscript and suggesting many helpful changes. This is Lamont-Doherty Earth Observatory Contribution No. 6886, and contributions to IGCP 458 and 506.

\section{References}

Aït Chayeb, E.H., Youbi, N., El-Boukhari, A., Bouabdelli, M., Amrhar, M., 1998. Le volcanisme permien et mésozoïque inférieur du bassin d'Argana (Haut-Atlas occidental, Maroc): un magmatisme intraplaque associé à l'ouverture de l'Atlantique central. Journal of African Earth Sciences 26 (4), 499-519 (in French).

Beerling, D.J., Berner, R.A., 2002. Biogeochemical constraints on the TrJT-J boundary carbon cycle event. Global Biogeochemical Cycles $16,101-113$.

Benton, M.J., 1995. Diversification and extinction in the history of life. Science 268, 52-58.

Berger, A.M., Loutre, M., Laskar, J., 1992. Stability of the astronomical frequencies over the Earth's history for paleoclimate studies. Science 255, 260-566.

Bertrand, H., 1991. The Mesozoic tholeiitic province of Northwest Africa; a volcanotectonic record of the early opening of Central Atlantic. In: Kampunzu, A.B., Lubala, T. (Eds.), Magmatism in Extensional Structural Settings; The Phanerozoic African Plate. Springer-Verlag, Berlin, pp. 147-188.

Bice, D.M., Newton, C.R., McCauley, S., Reiners, P.W., McRoberts, C.A., 1992. Shocked quartz at the Triassic-Jurassic boundary in Italy. Science $255,443-446$.

Boynton, W.V., 1984. Cosmochemistry of rare earth elements: meteorite studies. In: Henderson, P. (Ed.), Rare Earth Element Geochemistry. Elsevier, Amsterdam, pp. 63-114.

Briden, J.C., Daniels, B.A., 1999. Palaeomagnetic correlation of the Upper Triassic of Somerset, England, with continental Europe and eastern North America. Journal of the Geological Society 156, 317-326.

Bujak, J.P., 1977. Palynological Analysis of Mobil-Gulf Chinampas N-37, Bay of Fundy. Mobil Oil Corp. Rep. EPGS-PAL. 3-79JPB (technical report).

Carmichael, C.M., Palmer, H.C., 1968. Paleomagnetism of the Late Triassic, North Mountain basalt of Nova Scotia. Journal of Geophysical Research 73 (8), 2811-2822.

Cohen, A.S., Coe, A.L., 2002. New geochemical evidence for the onset of volcanism in the Central Atlantic magmatic province and environmental change at the Triassic-Jurassic boundary. Geology $30,267-270$.

Cornet, B., 1977. The palynostratigaphy and age of the Newark Supergroup. Ph.D. Thesis, Department of Geology, The Pennsylvania State University, State College, PA, 165-172, 192-222.

Cornet, B., Olsen, P.E., 1985. A summary of the biostratigraphy of the Newark Supergroup of eastern North America, with comments on early Mesozoic provinciality. In: Weber, R. (Ed.), Symposio Sobre Flores del Triasico Tardino st Fitogradia y Paleoecologia, 
Memoria. Proc. II) Latin-American Congress on Paleontology (1984). Instituto de Geologia Universidad Nacional Autonoma de Mexico, pp. 67-81.

Cornet, B., Traverse, A., 1975. Palynological contributions to the chronology and stratigraphy of the Hartford basin in Connecticut and Massachusetts. Geoscience and Man 11, 1-33.

de Boer, J.Z., Ernst, R.E., Lindsey, A.G., 2003. Evidence for predominant lateral magma flow along major feeder-dike segments of the eastern North America swarm based magnetic fabric. In: LeTourneau, P.M., Olsen, P.E. (Eds.), The Great Rift Valleys of Pangea in Eastern North America, v. 1: Tectonics, Structure, and Volcanism. Columbia University Press, New York, pp. 189-206.

Dostal, J., Greenough, J.D., 1992. Geochemistry and petrogenesis of the early Mesozoic North Mountain basalts of Nova Scotia, Canada. In: Puffer, J.H., Ragland, P.C. (Eds.), Eastern North American Mesozoic Magmatism. Geological Society of America Special Paper, vol. 268, pp. 149-159.

Ernst, R.E., Buchan, K.L., 1997. Giant radiating dyke swarms: their use in identifying pre-Mesozoic large igneous provinces and mantle plumes. In: Mahoney, Coffin, M. (Eds.), Large Igneous Provinces: Continental, Oceanic and Planetary Flood Volcanism. Geophysical Monograph, vol. 100, pp. 297-333.

Ernst, R.E., de Boer, J.Z., Ludwig, P., Gapotchenko, T., 2003. Magma flow pattern in the North Mountain Basalts of the 200 Ma CAMP event: evidence from the magnetic fabric. In: Hames, W.E., McHone, J.G., Renne, P.R., Ruppel, C. (Eds.), The Central Atlantic Magmatic Province: Insights From Fragments of Pangea. Geophysical Monograph Series, vol. 136, pp. 227-239.

Foote, M., 2003. Origination and extinction through the Phanerozoic: a new approach. Journal of Geology 111, 125-148.

Fowell, S.J., Olsen, P.E., 1993. Time-calibration of Triassic/Jurassic microfloral turnover, eastern North America. Tectonophysics 222, 361-369.

Fowell, S.J., Traverse, A., 1995. Palynology and age of the upper Blomidon Formation, Fundy Basin, Nova Scotia. Review of Palaeobotany and Palynology 86 (3-4), 211-233.

Fowell, S.J., Cornet, B., Olsen, P.E., 1994. Geologically rapid Late Triassic extinctions: palynological evidence from the Newark Supergroup. In: Klein, G.D. (Ed.), Pangaea: Paleoclimate, Tectonics and Sedimentation During Accretion, Zenith and Break-up of a Supercontinent. Geological Society of America Special Paper, vol. 288, pp. 197-206.

Galli, M.T., Flavio, J., Stefano, B., Helmut, W., 2005. Anomalies in global carbon cycling and extinction at the Triassic/Jurassic boundary: evidence from a marine C-isotope record. Palaeogeography, Palaeoclimatology, Palaeoecology 216, 203-214.

Gierlowski-Kordesch, E., Huber, P., 1995. Lake sequences of the central Hartford Basin, Newark Supergroup. State Geological and Natural History Survey of Connecticut Guidebook, vol. 7, pp. B1-B39.

Good, S.C., Yenik, L.A., Olsen, P.E., McDonald, N.G., 1994. Nonmarine molluscs from the Scots Bay Formation, Newark Supergroup (Early Jurassic), Nova Scotia: taxonomic assessment and paleoecologic significance. Geological Society of America, Abstracts with Programs 26 (3), 20.

Greenough, J.D., Jones, L.M., Mossman, D.J., 1989. Petrochemical and stratigraphic aspects of North Mountain basalt from the north shore of the Bay of Fundy, Nova Scotia, Canada. Canadian Journal of Earth Sciences 26, 2710-2717.

Guex, J., Bartolina, A., Atudorei, V., Taylor, D., 2004. High-resolution ammonite and carbon isotope stratigraphy across the TriassicJurassic boundary of New York Canyon (Nevada). Earth and Planetary Science Letters 225, 29-41.
Hallam, A., 1990. The end-Triassic mass extinction event. In: Sharpton, V.L., Ward, P.D. (Eds.), Global Catastrophes in Earth History; an Interdisciplinary Conference on Impacts, Volcanism and Mass Mortality. Geological Society of America Special Paper, vol. 247, pp. 577-583.

Hallam, A., Wignall, P., 2004. Discussion on sea-level change and facies development across potential Triassic-Jurassic boundary horizons, SW Britain. Journal of the Geological Society London 161 (6), 1053-1056.

Hames, W.E., Renne, P.R., Ruppel, C., 2000. New evidence for geologically instantaneous emplacement of earliest Jurassic Central Atlantic magmatic province basalts on the North American margin. Geology 28, 859-862.

Heilman, J.J., 1987. That catastrophic day in the Early Jurassic. Entombed vegetation in East Haven lava. Connecticut Journal of Science Education 25, 8-25.

Hesselbo, S.P., Robinson, S.A., Surlyk, F., Piasecki, S., 2002. Terrestrial and marine extinction at the Triassic-Jurassic boundary synchronized with major carbon-cycle perturbation: a link to initiation of massive volcanism. Geology 30, 251-254.

Hesselbo, S.P., Robinson, S.A., Surlyk, F., 2004a. Sea-level change and facies developement across potential Triassic-Jurassic boundary horizons, southwestern Britain. Journal of the Geological Society 161, 365-379.

Hesselbo, S.P., Robinson, S.A., Surlyk, F., 2004b. Discussion on sealevel change and facies development across potential TriassicJurassic boundary horizons, SW Britain: reply. Journal of the Geological Society London 161 (6), 1053-1056.

Hill, R.I., 1991. Starting plumes and continental break-up. Earth and Planetary Science Letters 104, 398-416.

Hodych, J.P., Hayatsu, A., 1988. Paleomagnetism and K-Ar isochron dates of Early Jurassic basaltic flows and dikes of Atlantic Canada. Canadian Journal of Earth Sciences 25, 1972-1989.

Hofmann, A., Tourani, A., Gaupp, R., 2000. Cyclicity of Triassic to Lower Jurassic continental red beds of the Argana Valley, Morocco: implications for paleoclimate and basin evolution. Palaeogeography, Palaeoclimatology, Palaeoecology 161, 229-266.

Hounslow, M.W., Posen, P.E., Warrington, G., 2004. Magnetostratigraphy and biostratigraphy of the Upper Triassic and lowermost Jurassic succession, St. Audrie's Bay. Palaeogeography, Palaeoclimatology, Palaeoecology 213, 331-358.

Hozik, M.J., 1992. Paleomagnetism of igneous rocks in the Culpeper, Newark, and Hartford/Deerfield basins. In: Puffer, J.H., Ragland, P.C. (Eds.), Eastern North American Mesozoic Magmatism. Geological Society of America Special Paper, vol. 268, pp. 279-308.

Hubert, J.F., Dutcher, J.A., 1999. Sedimentation, volcanism, stratigraphy, and tectonism at the Triassic-Jurassic boundary in the Deerfield basin, Massachusetts. Northeastern Geology and Environmental Sciences 21, 188-201.

Huynh, T.T., Poulsen, C.J., 2005. Rising atmospheric $\mathrm{CO}_{2}$ as a possible trigger for the end-Triassic mass extinction. Palaeogeography, Palaeoclimatology, Palaeoecology 217 (3-4), 223-242.

Kent, D.V., Olsen, P.E., 1999. Astronomically tuned geomagnetic polarity time scale for the Late Triassic. Journal of Geophysical Research 104, 12831-12841.

Kent, D.V., Olsen, P.E., 2000. Magnetic polarity stratigraphy and paleolatitude of the Triassic-Jurassic Blomidon Formation in the Fundy basin (Canada): implications for early Mesozoic tropical climate gradients. Earth and Planetary Science Letters 179 (2), 311-324.

Kent, D.V., Tauxe, L., 2005. Corrected Late Triassic latitudes for continents adjacent to the North Atlantic. Science 307, 240-244. 
Kent, D.V., Olsen, P.E., Witte, W.K., 1995. Late Triassic-earliest Jurassic geomagnetic polarity sequence and paleolatitudes from drill cores in the Newark rift basin, eastern North America. Journal of Geophysical Research 100, 14965-14998.

Knight, K.B., Nomade, S., Renne, P.R., Marzoli, A., Betrand, H., Youbi, N., 2004. The Central Atlantic magmatic province at the Triassic-Jurassic boundary: paleomagnetic and ${ }^{40} \mathrm{Ar} /{ }^{30} \mathrm{Ar}$ evidence from Morocco for brief, episodic volcanism. Earth and Planetary Science Letters 228, 143-160.

Kump, L.R., Arthur, M.A., 1999. Interpreting carbon-isotope excursions: carbonates and organic matter. Chemical Geology 161, 181-198.

Laskar, J., Robutel, P., Joutel, F., Gastineau, M., Correia, A.C.M., Levrand, B., 2004. A long-term numerical solution for the insolation quantities of the Earth. Astronomy and Astrophysics 428, 261-285.

Marzoli, A., Renne, P.R., Piccirillo, E.M., Ernesto, M., Bellieni, G., De Min, A., 1999. Extensive 200-million-year-old continental flood basalts of the Central Atlantic magmatic province. Science 284, 616-618

Marzoli, A., Bertrand, H., Knight, K.B., Cirilli, S., Buratti, N., Vérati, C., Nomade, S., Renne, P.R., Youbi, N., Martini, R., Allenbach, K., Neuwerth, R., Rapaille, C., Zaninetti, L., Bellieni, G., 2004. Synchrony of the Central Atlantic magmatic province and the Triassic-Jurassic boundary climatic and biotic crisis. Geology 32, 973-976

May, P.R., 1971. Pattern of Triassic-Jurassic diabase dikes around the north Atlantic in contrast to predrift position of the continents. Geological Society of America Bulletin 82, 1285-1292.

McElwain, J.C., Beerling, D.J., Woodward, F.I., 1999. Fossil plants and global warming at the Triassic-Jurassic boundary. Science 285, 1386-1390.

McHone, J.G., 2000. Non-plume magmatism and tectonics during the opening of the central Atlantic Ocean. Tectonophysics 316, 287-296.

McIntosh, W.C., Hargraves, R.B., West, C.L., 1985. Paleomagnetism and oxide mineralogy of upper Triassic to lower Jurassic red beds and basalts in the Newark Basin. Geological Society of America Bulletin 96, 463-480.

McRoberts, C.A., Furrer, H., Jones, D.S., 1997. Palaeoenvironmental interpretation of a Triassic-Jurassic boundary section from Western Australia based on palaeoecological and geochemical data. Palaeogeography, Palaeoclimatology, Palaeoecology 136, 79-95.

Morante, R., Hallam, A., 1996. Organic carbon isotopic record across the Triassic-Jurassic boundary in Austria and its bearing on the cause of the mass extinction. Geology 24, 391-394.

Oliveira, E.P., Tarney, J., Joao, X.J., 1990. Geochemistry of the Mesozoic Amapá and Jari dyke swarms, northern Brazil: plumerelated magmatism during opening of central Atlantic. In: Parker, A.J., Rickwood, P.C., Tucker, D.H. (Eds.), Mafic Dykes and Emplacement Mechanisms. Belkema, Rotterdam, pp. 173-183.

Olsen, P.E., 1984. Periodicity of lake-level cycles in the Late Triassic Lockatong Formation of the Newark Basin (Newark Supergroup, New Jersey and Pennsylvania). In: Berger, A., Imbrie, J., Hays, J., Kukla, G., Saltzman, B. (Eds.), Milankovitch and Climate. NATO Symposium. D. Reidel Publishing Co., pp. 129-146. Pt. 1.

Olsen, P.E., 1997. Stratigraphic record of the early Mesozoic breakup of Pangea in the Laurasia-Gondwana rift system. Annual Reviews of Earth and Planetary Science 25, 337-401.

Olsen, P.E., Kent, D.V., 1996. Milankovitch climate forcing in the tropics of Pangea during the Late Triassic. Palaeogeography, Palaeoclimatology, and Palaeoecology 122, 1-26.

Olsen, P.E., Kent, D.V., 1999. Long-period Milankovitch cycles from the Late Triassic and Early Jurassic of eastern North America and their implications for the calibration of the early Mesozoic time scale and the long-term behavior of the planets. Philosophical Transactions of the Royal Society of London (A) 357, 1761-1787.

Olsen, P.E., Shubin, N.H., Anders, P.E., 1987. New Early Jurassic tetrapod assemblages constrain Triassic-Jurassic tetrapod extinction event. Science 237, 1025-1029.

Olsen, P.E., Schlische, R.W., Gore, P.J.W. (Eds.), 1989. Field Guide to the Tectonics, Stratigraphy, Sedimentology, and Paleontology of the Newark Supergroup, Eastern North America. International Geological Congress, Guidebooks for Field Trips, vol. T351. 174 pp.

Olsen, P.E., McDonald, N.G., Huber, P., Cornet, B., 1992. Stratigraphy and paleoecology of the Deerfield rift basin (Triassic-Jurassic, Newark Supergroup), Massachusetts. In: Robinson, P., Brady, J.B. (Eds.), Guidebook for Field Trips in the Connecticut Valley Region of Massachusetts and Adjacent States. . New England Intercollegiate Geological Conference 84th Annual Meeting, Contribution no. 66, vol. 2. Department of Geology and Geography, University of Massachusetts, Amherst, Massachusetts, pp. 488-535.

Olsen, P.E., Kent, D.V., Cornet, B., Witte, W.K., Schlische, R.W., 1996a. High-resolution stratigraphy of the Newark rift basin (Early Mesozoic, Eastern North America). Geological Society of America 108, 40-77.

Olsen, P.E., Schlische, R.W., Fedosh, M.S., 1996b. 580 ky duration of the Early Jurassic flood basalt event in eastern North America estimated using Milankovitch cyclostratigraphy. In: Morales, M. (Ed.), The Continental Jurassic. Museum of Northern Arizona Bulletin, vol. 60, pp. 11-22.

Olsen, P.E., Kent, D.V., Fowell, S.J., Schlische, R.W., Withjack, M.O., LeTourneau, P.M., 2000. Implications of a comparison of the stratigraphy and depositional environments of the Argana (Morocco) and Fundy (Nova Scotia, Canada) Permian-Jurassic basins. In: Oujidi, M., Et-Touhami, M. (Eds.), Le Permien et le Trias du Maroc, Actes de la Premièr Réunion su Groupe Marocain du Permien et du Trias: Oujda, Hilal Impression, pp. 165-183.

Olsen, P.E., Kent, D.V., Sues, H.D., Koeberl, C., Huber, H., Montanari, A., Rainforth, E.C., Fowell, S.J., Szajna, M.J., Hartline, B.W., 2002a. Ascent of dinosaurs linked to Ir anomaly at TriassicJurassic boundary. Science 296, 1305-1307.

Olsen, P.E., Koeberl, C., Huber, H., Montanari, A., Fowell, S.J., EtTouhami, M., Kent, D.V., 2002b. Continental Triassic-Jurassic boundary in central Pangea: recent progress and discussion of an Ir anomaly. In: Koerberl, C., MacLeod, K.G. (Eds.), Catastrophic Events and Mass Extinctions: Impacts and Beyond: Boulder, Colorado. Geological Society of America Special Paper, vol. 356, pp. 505-522.

Olsen, P.E., Kent, D.V., Et-Touhami, M., Puffer, J.H., 2003a. Cyclo-, magneto-, and bio-stratigraphic constraints on the duration of the CAMP event and its relationship to the Triassic-Jurassic boundary. In: Hames, W.E., McHone, J.G., Renne, P.R., Ruppel, C. (Eds.), The Central Atlantic Magmatic Province: Insights from Fragments of Pangea. Geophysical Monograph Series, vol. 136, pp. 7-32.

Olsen, P.E., Whiteside, J.H., Huber, P., 2003b. Causes and consequences of the Triassic-Jurassic mass extinction as seen from the Hartford basin. In: Brady, J.B., Cheney, J.T. (Eds.), Guidebook for Field Trips in the Five College Region, 95th New England Intercollegiate Geological Conference. Department of Geology, Smith College, Northampton, Massachusetts, pp. B5-1-B5-41.

Olsen, P.E., Whiteside, J.H., Fedak, T., 2005. Field Trip A7: the Triassic-Jurassic faunal and floral transition in the Fundy Basin, Nova Scotia. Geological Association of Canada, Mineralogical Association of Canada, Canadian Society of Petroleum Geologists, Canadian Society of Soil Sciences Joint Meeting, Halifax, May 2005, AGS Special Publication Number 26, 53 pp. 
Pálfy, J., Demény, A., Haas, J., Hetényi, M., Orchard, M.J., Vetö, I., 2001. Carbon isotope anomaly and other geochemical changes at the Triassic-Jurassic boundary from a marine section in Hungary. Geology 29, 1047-1050.

Philpotts, A.R., Reichenbach, I., 1985. Differentiation of Mesozoic basalts of the Hartford basin, Connecticut. Geological Society of America Bulletin 96, 1131-1139.

Puffer, J.H., Lechler, P., 1980. Geochemical cross sections through the Watchung basalt of New Jersey, part 2. Geological Society of American Bulletin 91, 156-191.

Puffer, J.H., Philpotts, A.R., 1988. Eastern North American quartz tholeiites: geochemistry and petrology. In: Manspeizer, W. (Ed.), Triassic-Jurassic Rifting. Part B. Elsevier, New York, pp. 579-605.

Puffer, J.H., Hurtubise, D.O., Geiger, F.J., Lechler, P., 1981. Chemical composition and stratigraphic correlation of the Mesozoic basalt units of the Newark Basin, New Jersey, and the Hartford Basin, Connecticut. Geological Society of America Bulletin 92, 515-553.

Ragland, P.C., Whittington, D., 1983. Early Mesozoic diabase dikes of eastern North America: magma types. Geological Society of America Abstracts with Programs 15, 666.

Ragland, P.C., Cummins, L.E., Arthur, J.D., 1992. Compositional patterns for early Mesozoic diabases from South Carolina to central Virginia. Geological Society of America Special Paper 268, 309-331.

Rampino, M.R., Stothers, R.B., 1988. Flood basalt volcanism during the past 250 million years. Science 241, 663-668.

Royer, D.L., Berner, R.A., Beerling, D.J., 2001. Phanerozoic atmospheric $\mathrm{CO}_{2}$ change: evaluating geochemical and paleobiological approaches. Earth Science Reviews 54, 349-392.

Smith, W.A., 1987. Paleomagnetic results from a crosscutting system of northwest and north-south trending diabase dikes in the North Carolina Piedmont. Tectonophysics 136, 137-150.

Spray, J.G., Kelley, S.P., Rowley, D.B., 1998. Evidence for a late Triassic multiple impact event on Earth. Nature 392, 171-173.

Swift, A., 1995. Conodonts from the late Permian and late Triassic of Britain. Monograph of the Palaeontological Society, London 598, $80 \mathrm{pp}$.

Tanner, L., Kyte, F.T., 2005. Anomalous iridium enrichment at the Triassic-Jurassic boundary, Blomidan Formation, Fundy basin, Canada. Earth and Planetary Science Letters 240, 634-641.
Tanner, L.H., Lucas, S.G., Chapman, M.G., 2003. Assessing the record and causes of late Triassic extinctions. Earth Science Reviews 65, 103-139.

Tixeront, M., 1973. Lithostratigraphie et mineralisations cupriferes et uraniferes stratiformes syngenetiques et familieres des formations detritiques permo-triasiques du couloir d'Argana, Haut Atlas occidental (Maroc). Notes Serv. Geol. Maroc Tome 33, Nootes Mem. Serv. Geol., vol. 249, pp. 147-177.

Tollo, R.P., Gottfried, D., 1992. Petrochemistry of Jurassic Basalt from eight cores, Newark Basin, New Jersey: implications for the volcanic petrogenesis of the Newark Supergroup. In: Puffer, J. H., Ragland, P.C. (Eds.), Eastern North American Mesozoic Magmatism. Geological Society of America Special Paper, vol. 268, pp. 233-259.

Ward, P.D., Haggart, J.W., Carter, E.S., Wilbur, D., Tipper, H.W., Evans, T., 2001. Sudden productivity collapse associated with the TriassicJurassic boundary mass extinction. Science 292, 1148-1151.

Ward, P.D., Garrison, G.H., Haggart, J.W., Kring, D.A., Beattie, M.J., 2004. Isotope evidence bearing on late Triassic extinction events, Queen Charlotte Islands, British Columbia, and implications for the duration and cause of the Triassic-Jurassic mass extinction. Earth and Planetary Science Letters 224, 589-600.

Weigand, P.W., Ragland, P.C., 1970. Geochemistry of Mesozoic dolerite dikes from eastern North America. Contributions to Mineralogy and Petrology 29, 195-214.

Whiteside, J.H., Olsen, P.E., Sambrotto, R.N., 2003. Negative $\delta^{13} \mathrm{C}$ carbon isotopic anomaly in continental strata at the TriassicJurassic boundary in eastern North America (Newark Basin, Pennsylvania, USA). Geological Society of America 34 (7), 160.

Witte, W.K., Kent, D.V., 1990. The paleomagnetism of red beds and basalts of the Hettangian Extrusive Zone, Newark Basin, New Jersey. Journal of Geophysical Research 95, 17533-17545.

Witte, W.K., Kent, D.V., Olsen, P.E., 1991. Magnetostratigraphy and paleomagnetic poles from Late Triassic-earliest Jurassic strata of the Newark Basin. Geological Society of America Bulletin 103, $1648-1662$.

Yang, Z.Y., Moreau, M.G., Bucher, H., Dommergues, J.L., Trouiller, A., 1996. Hettangian and Sinemurian magnetostratigraphy from Paris Basin. Journal of Geophysical Research-Solid Earth 101, 8025-8042. 